\title{
Osmanlı IV. Ordûy-ı Hümâyunu'nda Kafkaslı Komutan Musa
}

\section{Paşa}

\section{Enver Konukçu*}

\section{Özet}

Musa Paşa, Kafkasyalı bir ailenin mensubu olup, Alkhas Kunduk'un ve Dölet Hanım'ın dört çocuğundan birisidir. 1818'de dünyaya gelmiştir. Kardeşlerinden Hasbulat Bey, Şeyh Şamil'in hizmetine girmiş ve Müridizm hareketine önemli katkılar yapmıştır. Musa Paşa, askerliğinin bir bölümünü 1837-1865 yılları arasında Çarlık Rusyası'nda geçirmiş ve bu aşamada generalliğe kadar yükselmiştir. 1866'da Büyük Kafkas veya Çeçen-Asetin göçünü gerçekleştirerek, Osmanlı hizmetine girmiş, vefatına kadar da Osmanlı subayı olarak hizmet etmiştir. 1866'da Padişah, Musa'ya mirlivalık rütbesi tevcih ederek, "Paşa” payesini verdi. Musa Paşa, Osmanlı Ordusu'nun en önemli askerî merkezlerinden olan Erzurum'a gelmiş, hatta ağabeyi Hasbulat Bey burada vefat etmişti. 1877-78 Osmanlı-Rus harbinde Musa Paşa Erzurum'daki IV. Ordu'da görev aldı ve Ruslarla ilgili bilgi ve tecrübelerini Osmanlı hizmetindeyken beraberindekilerle paylaştı. Erzurum ve çevresindeki tabyalarda Ruslarla yapılan çarpışmalarda etkin olarak görev yaptı. Ahmet Muhtar Paşa ve Mehmet Arif'in eserlerinde, Musa Paşa'nın söz konusu faaliyetlerinden çok geniş bir şekilde bahsedilmektedir. Musa Paşa Ruslarla yapılan barış görüşmelerinde de Rusça bilgisinden de istifade edilerek önemli roller ifa etti. Kubatı Hanım ile evlenmiş, Arslan ve Bekir Sami adlı iki evladı olmuştur. Hatıraları da yayınlanmıştır. 1888-89'da Erzurum'da vefat etmiş ve aynı şehirde defnedilmiştir.

Anahtar Kelimeler: Musa Bey Kundukhov, Kafkasya, Ruslar, Osmanlılar, IV. Osmanlı Ordusu, Erzurum

\section{Caucasian Commander Musa Pasha in the IVth Army of the Ottoman Empire}

\section{Abstract}

Musa Pasha as member of Caucasian family was one of the son of four children of Alkhas Kunduk and Dölet Hanım. He was born in 1818. One of his brother Hasbulat Bey had been in the service of Sheikh Shamil and made important contributions to Muridizm movement. Musa Pasha gave military

\footnotetext{
* Prof. Dr., Emekli Öğretim Üyesi. (ORCID ID: 0000-0003-0714-4819)

(Makale Gönderim Tarihi: 10.08.2017, Makale Kabul Tarihi: 16.09.2017)
}

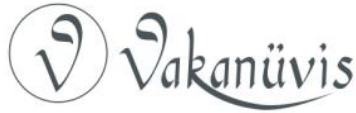


service in the Russian Army between 1837 and 1867 and became a general. In 1866, immigrated to the Ottoman Empire during Big Caucasian and Circassian-Asetin immigration and served as Ottoman soldier till his death. He became an Ottoman Pasha in 1866 by the rank of Brigadier General. Musa Pasha came to Erzurum one of the most important military bases of the Ottoman Empire and his brother Hasbulat Bey died in this city. Musa Pasha was part of Ottoman Army during 1877-1878 Ottoman-Rusian War and shared his experiences and knowledge about Russians with his comrades. He took effective roles during the fights against Russia around Erzurum bastions. In the works of Ahmet Muhtar Pasha and Mehmet Arif his activities are largely told. He used his fluent Russian at peace negotiations. He was married to Kubatı Hanım and had two sons named Arslan and Bekir Sami. His memories were published. He was dead in 1888-89 and buried at Erzurum.

Keywords: Musa Bey Kundukhov, Caucasia, Russians, Ottomans, VIth Ottoman Army, Erzurum.

XIX. Yüzyılda Erzurum, Kars, Van, Erzincan vs yerler Vilayât-ı Şarkıye diye biliniyordu. Önceleri Safeviler, Kaçarlar ve sonra da kuzeyden inen Ruslar sürekli olarak harp sahası haline getirmişlerdir. Türkmençay Andlaşması'ndan ${ }^{1}$ sonra doğuda, İranlıların yerini kuzeydeki Çarlık Rusyası almıştır. Çar Deli Petro'nun, ileriye dönük vasiyeti, sonrakilerce de unutulmamış, devletin toprakları Türkistan ve Kafkasya'ya doğru genişletilmiştir. Bazı batılı yazarlar, bu nedenle Kafkasya'yı, House of The War, yani Darü'l-Harb², savaşın anayurdu olarak nitelemişlerdir.

Osmanlılar, Rusların niyetlerini zamanla öğrendiklerinden, doğudaki ordularını her zaman teyakkuz hâlinde tutmuşlardır. Bununla da kalmayarak, savaş teknolojisinin gerekli kuruluşlarını da büyük mâli harcamalarla inşa etmişlerdir. Avrupa tarzı tabya adı verilen savunma hatları, Erzurum, Kars ve Ardahan taraflarında uygun yerlere yapılmıştır ${ }^{3}$. Eskiden Erzurum Beylerbeyiliği, sonra da Şark Seraskerliği

\footnotetext{
${ }^{1}$ Kerim K. Şükürov, Türkmençay-1828, Bakü 2006, s. 73-80.

${ }^{2}$ Rusların "Harp ve Sulh"üne benzer ifade, doğu- batı mücadelesinde, sürekli harplerin geçtiği yer Anadolu için kullanılmıştır. Catrine Gavin, The House of War, Newyork 1970.

${ }^{3}$ Tabyalar için bakınız: N. Çam, Erzurum Tabyaları, Ankara 1993, M. Küçükuğurlu, Erzurum Tabyaları ve Kışlaları, İstanbul 2013. Sonuncu eser, şimdiye kadar yazılmış önemli araştırmadır.
}

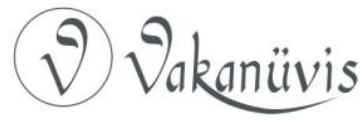


ve XIX. yüzyıl yarısından sonra da Osmanlı IV. Ordûy-ı Hümâyunu savunmaları üstlenmiş ve Ruslarla aralıklı büyük savaşlar yapılmıştır. Aynı hareketlilik, Rumeli'de göze çarpmış ve her iki cephede de büyük savaşlar olmuştur. XIX. yüzyıl başlarında Ruslar, Kafkasya'yı da istilâ ile Gürcüler, Abhazlar, Çerkesler ve Kabardeyler ile sonu gelmeyen kanlı savaşlar yapmışlardır ${ }^{4}$. General Paskiyeviç, General Muravyev ve son olarak da Loris Melikov, etkili Rus yayılmacılığını hayata geçirmişlerdir. Arpaçay sınırı zaman zaman aşılmış, Şüregel, Taht Düzü, Pasinler ve Erzurum bu istilâ hareketlerinin merkezleri olmuşlardır ${ }^{5}$. İstanbul, tabyaları Kırım Savaşı sonrasında hayata geçirmiş ve şehirler de devre-i muttasıla denilen Toprak Tabyalar ile düşmana karşı kurulmuştur ${ }^{6}$.

IV. Ordu da asker, iaşe ve ibate bakımından güçlendirilmiş ve gönüllü olarak da milisleri silâhaltına almıştır. Ordu komutanları da savaş bakımından oldukça yetenekli kişilerdir. Ordunun merkezi Erzurum, ön hatlardaki kuvvetler de Ardahan ve Kars'ta konuşlandırımışlardır. Gazi Ahmed Muhtar Paşa ${ }^{7}$, ordu komutanı olurken, yanına Türklerin yanı sıra yabancılar da verilmiştir. Bunlar, Prusyalı, İngiliz, Lehli/Polonyalı ve özellikle Macar kökenli tecrübeli subaylardır. Müslüman olan diğer komutanların başında, Şeyh Şamil'in oğlu Mehmed ve Musa Paşa ${ }^{8}$ geliyordu. Sonuncusunun hayatı ve üstlendiği görevler oldukça ilgi çekicidir. Musa Paşa, askerliğinin bir bölümünü, 1837-1865 yılları arasında, Çarlık Rusyası'nda geçirmiştir 9 . Burada generalliğe kadar yükselmiştir. 1866 'da ise Büyük Kafkas veya Çeçen-Asetin göçünü gerçekleştirmiş ve aşağıda temas edileceği gibi Osmanlıların hizmetine girmiştir. Aynı rütbe ile askerliğe kabul edilen Musa Paşa, bundan böyle ölümüne kadar Osmanlı subayı olarak görevde bulunmuştur. Yine temas edileceği gibi, Musa Paşa,

\footnotetext{
${ }^{4}$ John F. Baddeley, Rusların Kafkasyayı Istiası ve Şeyh Şamil, çvr: S. Özden, İstanbul 1989; William Edward, David Allen- P. Muratov, 1828-1921 Türk Kafkas Sınırındaki Harplerin Tarihi, Ankara 1966 (Caucasian Battefields: A History of the Wars on the Turco- Caucasian Borders 1828-1921, Cambridge 1953).

${ }^{5}$ Allen, a.g.e.

${ }^{6}$ Küçükuğurlu, a.g.e., s. 31, 49, 56-57, 98-100.

${ }^{7}$ Gazi Ahmet Muhtar Paşa, Anılar: Sergüzeşt-i Hayatımın Cild-i Sanisi, hzl: Y. Demirel, İstanbul 1996, s. 8 v.d.

${ }^{8}$ Gazi Ahmed Muhtar Paşa, a.g.e., s. 187-279.

${ }^{9}$ T. C. Kutlu, "Çerkes Musa Kundukhov Paşa (1818-1889)", Tarih ve Toplum, sayı:36 Aralık 1980, s. 47-48.
}

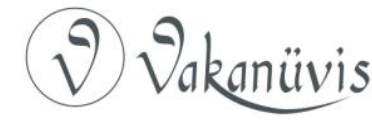


Osmanlılar için olağanüstü gerekliliği olan düşman dili Rusçayı da en iyi şekilde bilen biri idi. Bunun faydalarını da görmüştür. Şeyh Şamil'den sonra, milli direnişin, Osmanlı tarafında, önemli temsilcisi Şamiloğlu Mehmed ve Musa Paşa, deruhte etmiştir. Daha ziyade Kafkasyalı gönüllüler veya batılılara göre Başıbozuklar ile inanılmaz kahramanlıklar sergilemişlerdir.

\section{Çeçen/Asetin Exodus'u}

İnsanoğlunun göç tutkusu, tabi ki zorunlu şartlar nedeniyle meydana gelmiştir. Türklerin batıya, Hazar Denizi kuzeyinden geçerek yer değiştirmeleri de Kavimler Göçü olarak tanımlanmıştır. Kutsal kitaplara göre, Exodus, Mısır'da, Hz. Musa'nın kavmini eski topraklara taşıması ve bu arada denizi asasıyla yarması, unutulmuş değildir.

Garip bir tesadüftür ki, bir başka Musa da kabilesini, Kafkasya'dan alıp Halife-i Rûy-ı Zemin'in topraklarına, yani Osmanlı sınırları gerisine taşıması da XIX. yüzyılın ikinci yarısında meydana gelmiştir. Bunu büyük bir sorumluluk altında gerçekleştiren Musa Kundukhov olmuştur. Adı geçenin meşhur hatıratında olaya yer verilmekte ve kaynaktan iktisabla, Tarık Cemal Kutlu, şunları kaydetmektedir ${ }^{10}$ :

"Terek Eyâlet Komutanı General Mihail Tarieloviç Loris Melikov, Çeçenleri Küçük Kabardey'e sürmek amacıyla Batı Kafkasya'daki kuvvetleri Çeçenia üzerine sevk etti. Major General Musa Kondukhov, bunun üzerine General Melikov ile görüşerek, Çeçenlerin Osmanlı ülkesine göçlerini önerdi. Önerisi kabul edildi. Musa Kundukhov, vakit kaybetmeden, Rus üniformalı olarak, Haziran 1863 'te İstanbul'a gitti. O sırada devletin başında pâdişâh olarak Abdulâziz bulunuyordu. Hariciye Nâzırı Mehmed Emin Âlî Paşa, sonra da Sadrâzâm Mehmed Fuad Paşa ile görüştü. Teklif olumlu karşılandı. Her yıl 5000 kadar muhacir kabul edilebileceği bildirildi. Bir buçuk ay kadar, İstanbul'da ikâmette bulundu. Sonra, Karadeniz'de taşımacılık yapan Konstantin vapuruyla Odessa'ya yolculuk yaptı. Rusya da genel olarak Çeçen göçüne rıza gösterdi."

Böylece yarım asra yakın Rus üniforması taşıyan ve generalliğe kadar yükselmiş bulunan Musa Kundukhov, Mart 1865'te Kafkasya'dan

${ }^{10}$ Kutlu, a.g.m., s. 48.

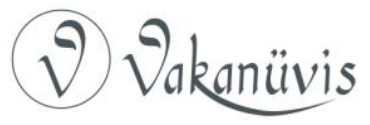


ayrıldı. Kafkas ardındaki Gümrü'ye ulaşıldı. Böylece, Çeçen Exodus'u hareketlenmiş oldu. Az sonra da Musa Paşa, Osmanlı toprağındaki Kars'a geçti. 3 Ağustos 1865 tarihli belge ile Çeçenler, Osmanlı himâyesine geçti. ${ }^{11}$

\section{"ERZURUM'DA BULUNAN ÇEÇEN MUHACIRLERIN ISKAN VE YERLERINE SEVKi}

Erzurum'da toplanarak Kars'taki kafile başkanları General Musa Bey Adındaki şahıs gelmedikçe bir tarafa gitmeyeceklerini bildiren çeçen muhacirlerin, zor kullanılarak iskân yerlerine sevk edilebilecekleri.

\section{Ağustos 1865}

\section{Nusret Paşa'ya cevabnâme-i telgrafí}

Fî 27 S. sene (12)82 tarihli telgraf mektubları görüldü.

Eğerçi ol bâbda Erzurum'a tecdid-i vesâyâ olunmuş ise de oradan alınan telgrafnâme me'âline göre Erzurum'a gelen kafilenin rüesâsı Kars'dan vürûduna müntazır oldukları ümera gelmedikçe ileriye hareket etmeyeceklerini sûret-i kat'iyyede ifade edip tarafinıza beyân-ı hâl kılınmış ise de henüz cevabı zuhûr etmediği bildirilmişve binâberîn işin iki taraflı tutulması taht-ı lüzûmda görülmüş olmağla seri'an bi'lmükâtebe hüsn-i ıslah-ı esbâb-ı sevkiyyeye himmet ve itina eylemeniz matlûbdur.

Fî 6 Ra. Sene(12)82

\section{Tahrirât-ı Telgrafiye}

\section{Numara 361}

Mektub Gönderen Merkez: Erzurum

Erzurum'da yığılıp General Musa Bey gelmedikçe bir tarafa gitmeyen Çeçen muhâcirleri dört bine kârib olup devlet ve milletce eyledikleri zâiyat şöyle dursun istihkâmat için dahi beş bin kadar asâkir$i$ redîf mevcud olduğundan ve muhâcirîn-i merkûmûnun mizâc ve meşvâları icabınca az şeyden çukasını çıkararak kavga ile nihayetü'lemr bir fenalık hudûs-ı akreb me'mûl olup eğerçi bir saat evvel merkezlerine sevk edilmek için ya mûmâileyh Musa Bey'in buraya gönderilmesi veyâhud kendisinin bizzat gelmesi saâdetli Nusret Paşa'ya

11 Osmanlı Belgelerinde Kafkas Göçleri, (Proje Yöneticisi: Prof. Dr. Uğur Ünal), İstanbul 2012, s. 362-363.

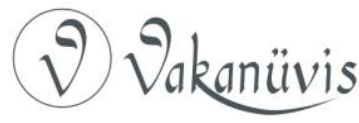


yazıldı ise de ona da cevab alınamadığından ve mesbûk olan arzve iş'ârI çâkerânem vechile bunlara sûret-i cebriye gösterilmedikçe bir ayak ileri gitmeyeceklerinden bu bâbda ne vechile hareket etmek lazım edilmek lâzım geleceğinin istizânıyla Cenâb-ı Hak hıfz eylesin bir fenalık zuhûr ederse mes'ul olmamak için arz ve iş'âra ictisâr eyledim. Ferman.

Fî 22 Temmuz sene (12)81 (3 Ağustos 1865)"

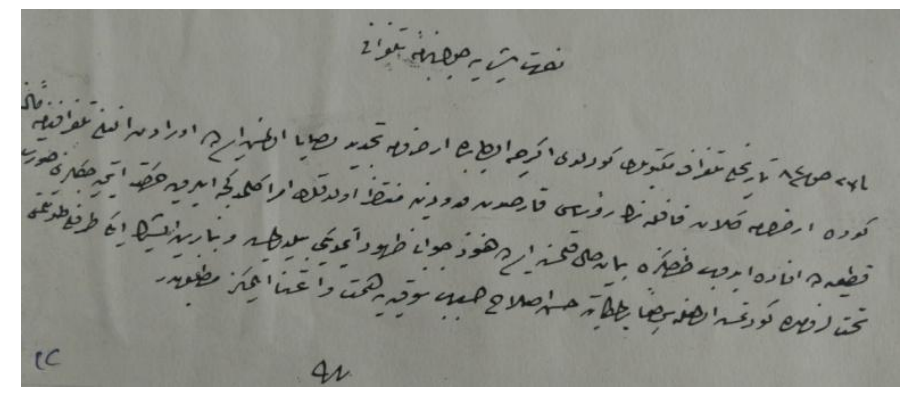

Osmanlı ülkesinin yeni vatandaşları arasında tabii ki Musa ve yakınları vardı. O'nun Hanımı Kubatı, büyük oğlu Arslan Bek, Bekir Sami, kardeş Afako ve Hasbulat Bey isimleri ön plânda idi. Fransız önderlerinden ve edebiyatçılarından Lamartin'e benzetilen Mamsıratı Temirbolat gibi "büyük ozan" da göze çarpmakta idi. Çeçenler, daha sonra, Erzurum, Erzincan yolu ile Sivas'a, Tokat'a gittiler. Sivas'ın Âziziyesinde, Saroz'unda Çeçen yerleşmeleri zamanla tamamlandı. Kunduk ailesi bu arada Tokat civârında, güneydoğuda, yol üzerindeki Batmantaş'ta konak satın alarak orada oturmuştur.

1866'da, Pâdişâh, Musa'ya Mîrlîvalık rütbesi tevcih etti. bundan sonra da kaynaklarda "Paşa" ve "Çerkes" olarak geçen Musa bey takiben de, Erzurum'a hareket etti ve Osmanlı IV. Ordûy-ı Hümâyûn'da, Mîrlîva olarak görevine başladı. Ancak, Musa Paşa, ikinci dönem hatıralarını yazmamıştır. Belki de ele geçmemiştir. 1876-1889 arasındaki savaşlar ve barış devresinde, diğer Osmanlı subayları gibi kendisinden söz ettirmiştir.

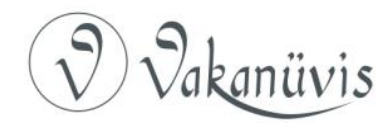




\section{Hasbulat Bey'in Ölümü (1866)}

Ali Kantemir'in Exodus olarak nitelendirdiği büyük Kafkas göçü ${ }^{12}$, peyder pey Rusya'dan Osmanlı ülkesine devam etmiştir. Musa Bey de kendi kabilesini önce Kars'a sonra da Erzurum'a intikal ettirebilmiştir. Ancak, yakını Hasbulat Bey, Erzurum'da iken rahmetli oldu. Muhtemelen elli yaşlarında idi. Alkhas Kunduk ile Dövlet Dudar Hanım baba ve annesi oluyordu. Musa, Hamurza, İdris, Afako ve Musa oğullar içinde cesurluğu ile tanınan kimse idi. Musa'nın Rus Çarlığında asker olması ve generalliğe kadar yükselmesine karşın Hasbulat, müridizm akımının Şeyh Şamil yanında önemli bir şahsiyet olarak göze çarpmıştı. Kardeşler arasında, Hamurza da kendi tarafında idi. Ancak, aile içinde her hangi bir ayrılık bahis konusu değildi. 1844'de Hamurza, Çeçenia savaşında vefat etmişti. Onun halefi olarak da Hasbulat göç ile Erzurum'a geldiğinde, hayatını kaybetmişti ${ }^{13}$. Şeyh Şamil, Gunip'de, Rus Baryatinsky'e teslim olmuş ve bu da Hasbulat nezdinde tabii olarak büyük bir üzüntü yaratmıştı. Şeyh Şamil ile göç nedeni ile bir daha görüşme imkânları olmadı. Nedeni belirtilmeyen ölümü hicri Rebiülevvel 1283 'tür. Miladi karşılığı ise 10 Ağustos 1866 Cumartesi günüdür. Erzurum'daki Çeçenlerin, vilâyet ileri gelenleri ve bir kısım ahâlinin katılımı ile cenaze namazı, Tebriz Kapusundaki ve Çifte Minarenin yanı başındaki Narmanlı Câminde kılınmıştı. İslâmi ve Çeçen usûlüne göre, aynı caminin güneyindeki alanda, toprağa verilmiştir. Erzurum'un meşhur Kanber Taşında yapılan ve kitâbesi de meydana getirilen mezar, Erzurum tarihi üzerindeki çalışmamızda bulunmuş ve kamuoyuna duyurulmuştur. Daha sonra Yrd. Doç. Dr. S. Tozlu da biraz güçlükle okunan mezar kitâbesini bir kelime hariç çözebilmiştir. Kitabenin daha düzgün Osmanlıca metni yine aynı öğrencimize aittir. Yedi satırlık örneği günümüze kadar pek zarara uğramadan gelebilmiştir $^{14}$. Çeçen-Rus mücadelesi sırasında Cevher Dudayev zamanında bazı Çeçen temsilciler Erzurum'a geldiklerinde merhumun

\footnotetext{
${ }^{12}$ Les Memories du General Mouusa Pacha Kundoukhov (1837-1865), Paris 1939, s. 14. Hatıratın kopyasını Paris yolu ile sağlayan Prof. Dr. E. Şahin'e sonsuz teşekkürler.

${ }^{13}$ A.g.e., s. 14.

${ }^{14}$ Selahattin Tozlu, Zivin savaşından Berlin Antlaşmasına Kadar Erzurum (1877/1878), Atatürk Üniversitesi Sosyal Bilimler Enstitüsü Tarih Eğitimi ABD, Basılmamış Yüksek Lisans Tezi, Erzurum 1991, s. 99.
}

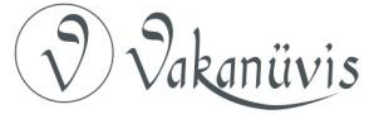


mezarını ziyâretle onun için okumuşlardır. Böylece, bir asır sonra, bu aziz insanın ruhu şâd edilmiştir.

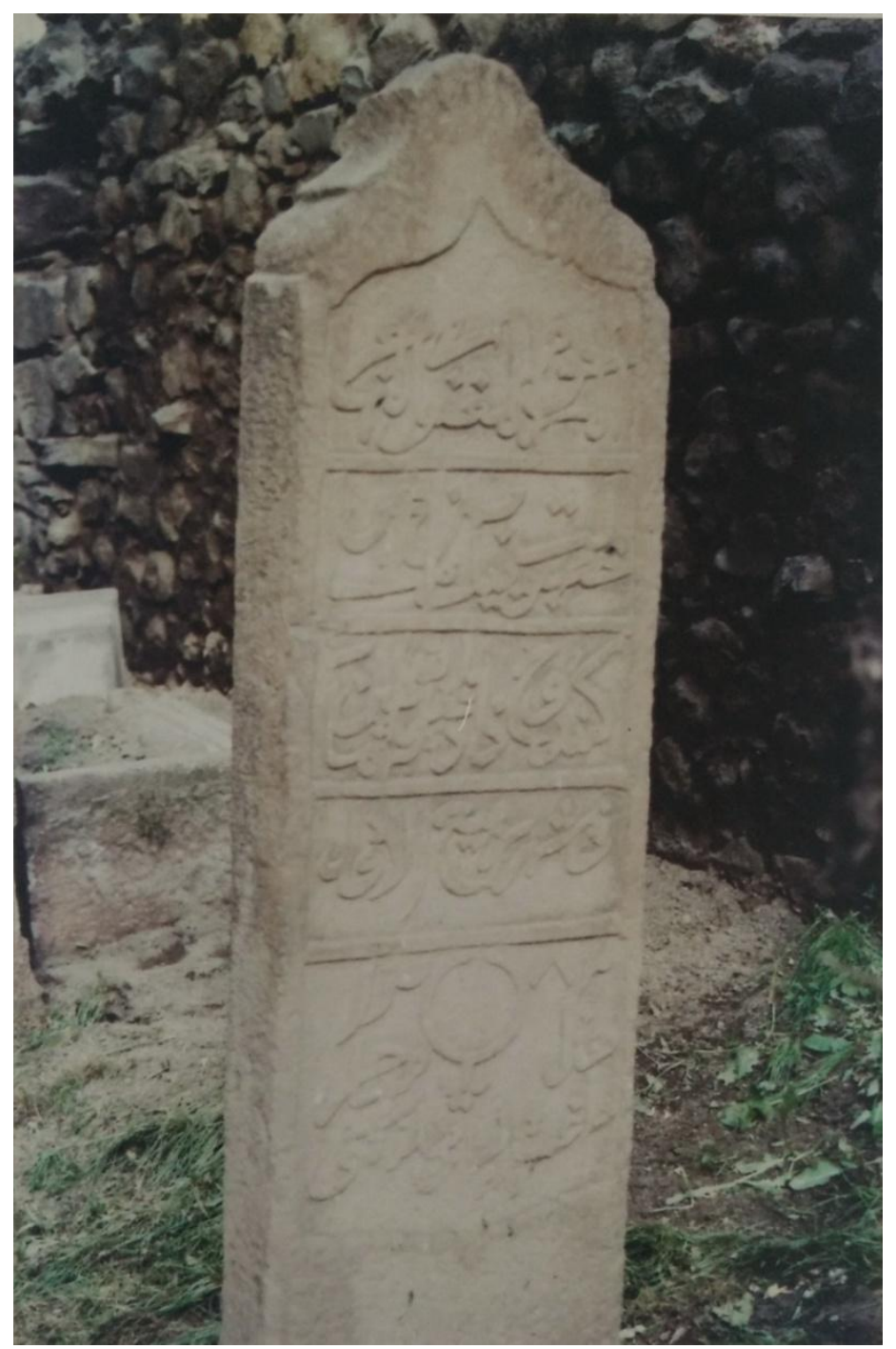

Hasbulat Bey bin Alhas'ın Narmanlı Câmii Haziresindeki Mezarı

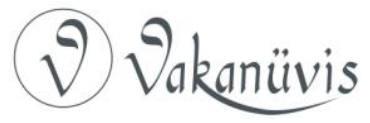




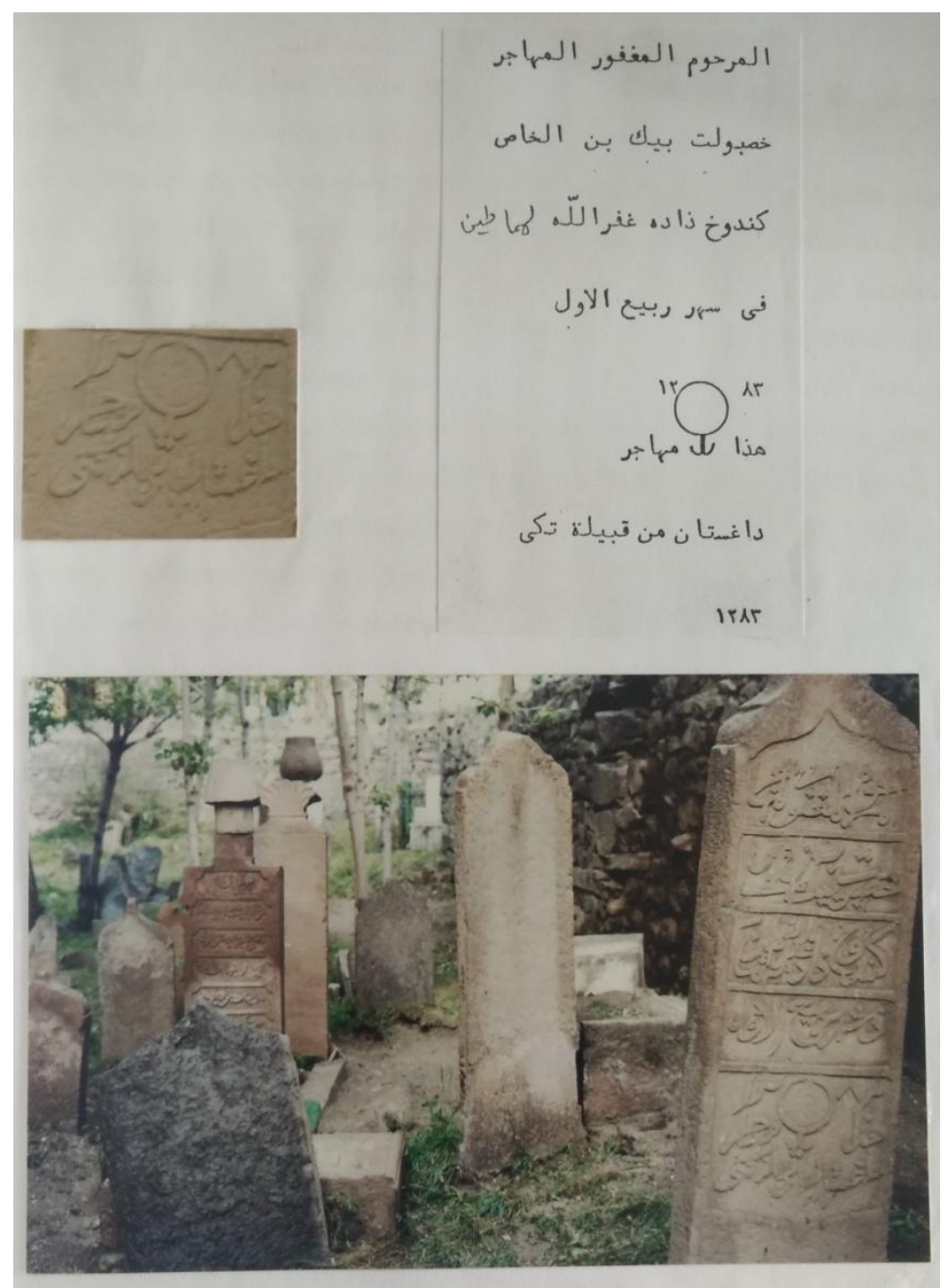

\section{Musa Paşa'nın Ağabeyi Hasbulat Beğ'in Mezarı (ö: 1283/1866)}

Kitâbe metni dikkatlice incelendiğinde bazı kültür kelimeleri de kendisini göstermektedir. Kendisinin muhacir olduğu öncelikle vurgulanmıştır. Türkçedeki Beğ unvanı da Kafkas veya Çeçen söyleyişindeki Big'dir. Rusça metinlerde ve tabii yaygın şekli ile Alkhazoviç, burada Alhas imlasına sahiptir. Doğru olanı da budur. Bir çok metinde aile ismi Kundukhov'dur. Ama, kitâbede Kunduhzâde diye

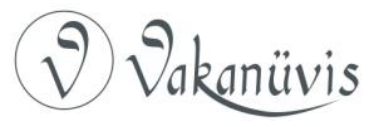


işâret edilmiştir. Beşinci satırda ölüm tarihi yazılmıştır. Galiba aile arması da daire ve altında çengelli şekli ile göze çarpmaktadır. Ölüm tarihi ay olarak belirtilmiştir ki, Rebiülevvel 1283 'dür. İşâret edildiği gibi miladi 14 Temmuz, 10 ağustos 1866 tarihine karşılıktır. Dağıstan kökenli kabi de Tki İmlası ile göze çarpmaktadır. Ancak, zorla harfleri tesbit edilebildiğine de işâret edelim. 1877-1878'de Erzurum'a gelen reisler ve Kafkasyalılar da onun mezârını ziyâret etmiş olmalılar ki, bunlar arasında Musa Paşa'ya yakınlığı ile tanınan İmam Şamil'in oğlu Gâzi Mehmed Paşa da bulunmaktadır. Kitâbenin ikinci satırındaki Hasbulat Big bin Ahlas Kunduhzâde'deki Hasbulat aslında Türkçedir. Has ve Bulat'tan ibarettir. Kanbolat, Canbolat, Temirbolat ve Mayri Biy Bulat gibi örnekleri de vardır. Bolat/Bulat sonuçta çelik anlamına gelen Pulat'dır.

\section{Osmanlı Mîrlîvası Musa Paşa (1867-1878)}

Osmanlı Ordus'unun Anadolu'daki en önemli askeri merkezi Erzurum idi. Musa göç sonrası bu tarihi kenti yakından görmüş ve hatta ailesinden Hasbulat, aynı şehirde vefat etmiş ve toprağa verilmişti. Daha sonra, bilindiği gibi Çeçen - Asetinler ile birlikte, onların başı olarak Sivas ve Tokat taraflarına gidilmiş ve devletin gösterdiği yerlerde yerleştirmişlerdi. Tokat yakınlarındaki Batmantaş'taki meşhur konağında pek fazla kalmayan, Musa, bu arada istanbul ile temasa geçmiş ve orduya kabulü için ariza kaleme almıştı. Bu dilekçesinde, IV. Ordû-ı Hümâyûn'da görev istediğinde bulunmuş ve bazı Rus dönemine ait belgeleri de göndermiştir. Pâdişâh da, kendisine arz edilen belgeyi görmüş ve orduda görevlendirmesine emir vermiştir. Daha sonra, "Çerkes" ve "Paşa" sıfatı ile Erzurum'a gitmiş, orada IV. Ordu Komutanı ile görüşerek, vazifesine başlamıştır ${ }^{15}$. Ordu Komutanı Ahmet Muhtar Paşa, düzenlemeleri yapmış Tabyaları yerinde görerek, gerekli talimatı vermiştir. Bu arada Musa Paşa da, IV. Ordu erkânı içinde yer almıştır. Erzurum'daki Rus Konsolosunun 19 Nisan 1877'de ayrılması hayırlı fal sayılmamış ve yakında, Rusların askeri hârekata geçebileceği düşünülmüştü ${ }^{16}$. Paşa, Rusca da bildiği için, haber kaynaklarından elde

\footnotetext{
${ }^{15}$ Mehmed Arif Bey, Başımıza Gelenler, hzl: E. Düzdağ, İstanbul 2009, s. 189, 226-227.

${ }^{16}$ Taranev hakkında bilgiler azdır. 1877 öncesi Erzurum'da görevlendirilmişti. Konsoloshaneye kapanıp kalmamış, Erzurum ve çevresini turist gibi gezmiştir.
}

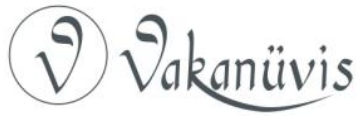


ettiği bilgiler de, genel savaşın Rumeli ve Anadolu'da başlayacağı düşüncesinde idi.

Erzurum, 1828-1829,1855'de Rus baskısına uğramış ve ilkinde geçici olarak da ele geçirilmişti ${ }^{17}$. İngilizlerin önerisi ile Rusların genel bir hücûmda Anadolu kalelerini ele geçirebileceği, onun için askeri savunma hatlarının yani tabiyelerin yapımı gerektiği konusunda fikir ileri sürmüşlerdi. Devlet, mâli sıkıntılara rağmen ahâlinin de yardımı ile Ardahan, Kars ve Erzurum'da inşâatlar yapmıştı. Musa Paşa geldiğinde de bunlar savunmaya hazır hâle getirilmişti ${ }^{18}$. Osmanlı-Rus Savaşı'nın Anadolu kısmında ilk hareketlenme 24 Nisan 1877 'de göze çarpmıştı. Savaşı ilan eden taraf tabii ki Rusya idi ${ }^{19}$. Bütün hazırlıklarını tamamlayan Ruslar, Şüregel'deki Arapçayı'nı geçerek, batıya doğru ilerlemişlerdi. Musa Paşa eski deneyimlerine göre. Rusların bir kaç cepheden Iğdır-Kars ve sonra da Erzurum yönünde harekete geçeceklerini önceden sezebilişti ve bazı husûslarda IV. Ordu Komutanına da yardımcı olmakta idi. Osmanlı Rus savaşlarına ait bir Çok yerli ve yabancı kaynak mevcuttur ${ }^{20}$. Ahmet Muhtar, Mehmed Ârif, Celâleddin Paşa, Ahmed Midhat gibi yazarlar da detaylı bilgiler vermişlerdir $^{21}$. İngiliz, Avusturya v.s yabancılar da savaşaları yakından görmüşler ve anlatmışlardır ${ }^{22}$. J.F. Baddeley'den ${ }^{23}$ sonra W.E.D. AllenP. Muratoff ${ }^{24}$ Rusların Erzurum önlerine gelişine kadarki dönemi kaynaklara dayalı anlatmışlardır. Musa paşa'nın etkinlikleri ise Ahmet Muhtar ve Mehmed Arif'in eserlerinde bahis konusu edilmiştir ${ }^{25}$. Bu arada eski Anion harabesinin civarındaki Alacadağ hakkında da bizzat

\footnotetext{
${ }^{17}$ Allen, a.g.e., s. $25-45$.

${ }^{18} 3$ nolu nota bakınız

${ }^{19}$ Mehmed Arif Bey, a.g.e., s. 130 v.d

${ }^{20}$ W. Greene, The Russian Army and its Campaigns in Turkey, Newyork 1879. C. B. ise gazetecidir. Time'ın "Seat of Wars" dur. Onun eseri de Armenia, and The Campaign of 1877, London ismini taşımaktadır.

${ }^{21}$ Mahmud Celaleddin Paşa, Mir'at-ı Hakikat, hzl: İ. Miroğlu, İstanbul 1983; Ahmed Mithat Efendi, Zübtetü'l-Hakayık, hzl: Ö. F. Can, Ankara 2015.

22 Rudolf von Schuluga, 1295/1877 Osmanlı- Rus Seferinde Haliyas-Zivin-Kars Muharebeleri, çvr: Yakub Şevki, İstanbul 1326/1910.

${ }^{23}$ Baddeley, a.g.e.

${ }^{24}$ Allen, a.g.e.

${ }^{25}$ Gazi Ahmet Muhtar Paşa, a.g.e, birçok yerde.
} 
Musa Paşa, Ahmed Muhtar Paşa'ya bilgi vermiştir. Bu Ârizası ${ }^{26}$ dışında ise savaşların gidişatı ve önerileri ve sonuçları hakkında nedense hatırat kabilinden de olsa geriye bir eser bırakılmamıştır. 1985 'de ise "Osmanlı Devri 1877-1878 Osmanlı Rus Harbi: Kafkas Cephesi Harekâtı, Ankara 1985" da daha gerçekçi ve belgeli bilgi de kaleme alınmıştır ${ }^{27}$. Şüregel'deki savaşlar, Taht Düzü yolu ile Köprü Köy'e çekiliş, Erzurum'daki savunma ve sonunda yenilgiyi içeren bilgiler hakkında, Musa Paşa ile ilgili olarak Mehmed Ârif Bey tarafından kısmı bilgiler verilmiştir $^{28}$. Bu tarihi akış içerisinde Musa Paşa'nın karşısındaki Ruslar ve komutanlar da hep vaktiyle kader birliği ettiği kimselerdi. Heimann, Lazarof, Loris Melikov v.s kimseler bunlar içinde idi. Musa Paşa'nın da içinde yer aldığı birçok Osmanlı-Rus çatışması önce Rusların geri çekilmesi sonra, Arapçay'ın batısından gerçekleştirdikleri Şüregel Savaşları, Taht Düzü, Soğanlı Dağları çekilişi, Horasan ve Köprü Köy, daha sonra da Pasinler Ovasından, Hasan Kaleden Höyüklerden mevzilenme, Aziziye sonrası Erzurum muhasarasında devam etmiştir. Son olarak da Kiremitlik Tabyası ile İstanbul kapısının savunulmasında Musa Paşa da bulunmuştur ${ }^{29}$.

Omanlı Orduy-ı Humayunu Kitabetinde, yazışmalarında görevli Erzurum'lu Mehmed Ârif Bey, yer yer, ilgisi dolayısıyla Musa Paşa İle etkinliklerinden bahsetmiştir. Bunlar özetle şöyledir ${ }^{30}$ : " Çerkes atlıları Kars taraflarında dolaştırıldı. Onlara baş olarak Musa Paşa tayin edildi. Yanına Kurmay Yarbay Şevket Bey de katıldı. Paşa iki top ile takviye edildi. Kars yolundaki Benli Ahmet'te Çerkesler Rus baskınına uğradı. Geceleyin kimin ne yaptığı belli olmadı. Karanlıkta göğüs göğüse kılıç muharebesi oldu. Daha sonra bütün atılır geri döndüler. En sonunda Komutanları Musa Paşa ile Şevket Bey de yaralı olarak hayatlarını kurtarabilmişlerdi. Diğer taraftan Musa Paşa, Bey veya Özden olmadığından asaleti bahis konusu edilmişti. Zaten Musa Paşa da

\footnotetext{
${ }^{26}$ R. Uçarol, Gazi Ahmed Muhtar Paşa: Bir Osmanlı Paşası ve Dönemi, İstanbul 1976, 483. Alacadağ vakası hakkında Musa Paşa'nın Gazi Ahmed Muhtar Paşa'ya takdim ettiği ariza, İstanbul (tarihi yok)

${ }^{27}$ S. Sükan, Osmanlı Devri, 1877-1878 Osmanlı Rus Harbi, Kafkas Cephesi Harekatı, Ankara 1985.

${ }^{28}$ Mehmed Arif Bey, a.g.e., s. 539-558.

${ }^{29}$ Mehmed Arif Bey, aynı yer.

${ }^{30}$ Mehmed Arif Bey, a.g.e., s. 228, 231, 236-237, 265-268.
}

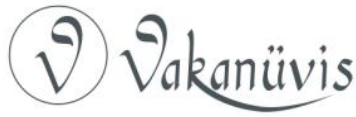


onlara epeyce kızmıştı. O yüzden yerine takiben Edhem Paşa atanmıştır. Halyas'da Ruslarla tekrar savaş meydana geldi. Musa Paşa, kendi kuvvetleri ile sol kolda görülmekte idi. Ahmed Muhtar paşa'nın son emirleri de Musa Paşa tarafından yerine getirilmiştir. Şüregel'deki Gedikler muharebesinde birçok kumandan Kaptan Mehmed Paşa ${ }^{31}$ gibi Musa Paşa'da gayret göstermişti. Ordu Komutanı gibi Sadrazam'da telgrafla bu zaferi, dolayısıyla Musa Paşa'yı da kutlamıştı. Yine Mehmed Arif Bey'in kaydettiği gibi Alacadağ'da Ruslar beklenmedik üstünlük kazandılar. Etrafı çevrilen birçok komutan protokol ile teslim oldu. Bunlara karşı çıkan tek komutan Musa paşa olmuştu" Güneş batalı bir buçuk saat olmuştu. Musa paşa Alacadağ'daki taburlarının yanına giderek, kendisinin teslim olmayıp, savaşacağını ve ayağına güvenenlerin beraber bulunabileceklerini herkese bildirdi. Onlardan sadece bir binbaşı ile Kurmay Kolağalarından Danyal Efendi Musa Paşa ile birlikte olmuşlardı. Musa paşa da geceleyin çıktığı yerden ileride Rusların hattına rastladı. Fakat Rusça yüksek sesle hâle ve mevkie uygun bazı sözler söyledi. Karakol askerleri de kendisini Rus Subayı zannederek geçmesine engel olmadılar ${ }^{32}$.

Musa Paşa sonunda, genel çekilişte Ahmed Muhtar Paşa ile Erzurum'a döndü. Bu sırada Aziziye savaşı oldu ve az sonrada Ruslar Erzurum'u kuşattılar. Kendi payına düşen savunma hattı şehrin Devre-i Muttasıla'daki Kiremitlik Tabyası ile İstanbul Kapısı arası olmuştur ${ }^{33}$.

Daha sonra, İstanbul IV.Orduûy-ı Humâyun Komutanı'nı geri çağırdı. Mehmed Ârif Bey de birlikte olduğu halde vedalaştı̆̆ı subaylar arasında Musa Paşa da bulubuyordu. Yerine, Kurd İsmail Paşa bırakıldı. Musa Paşa da onun yardımcısı idi. Bundan sonraki gelişmeler ilgi çekicidir. Ruslar Erzurum civarındadır. Kış şartları hem onlarıve hem de Türkleri zorlamaktadır. Sonunda, İstanbul'dan gelen telgraf, 31 Ocak 1878'de Edirne'de Mütareke yapıldığı yönünde $i d i^{34}$. Mütarekeye göre taraflar arasında savaş bitmiş idi. İsmail Hakkı Paşa, kendisine ulaşan telgraf ile durumu daha iyi öğrenebildi. Biraz sevinç biraz üzüntü içinde yanındaki

\footnotetext{
${ }^{31}$ Mehmed Arif Bey, a.g.e., s. 509-634. Ayrıca bakınız: Özel kitaplığımız, Kaptan Mehmed Paşa Dosyası, Erzurum 2011.

${ }^{32}$ Mehmed Arif Bey, a.g.e., s. 548.

${ }^{33}$ Mehmed Arif Bey, a.g.e., 676.

${ }^{34}$ Mahmud Celalleddin Paşa, a.g.e., s. 542-543.
}

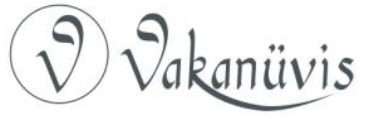


Musa Paşa da bilgilendirildi. Bu sırada görüşmelerde ön plana çıkan kişi Loris Melikov idi ${ }^{35}$ ve oda Musa Paşa'nın Rus Ordusunda iken tanıdığı idi. Rusların Erzurum'a girişi ise 8 Şubat 1878 idi $^{36}$. Tabii Musa Paşa en üzüntülü günlerinden birini yaşıyordu. Ön Barış Andlaşması yapıldı ${ }^{37} 3$ Mart 1878' Ayastaphanos/Yeşilköy. Dört ay sonra da 13 Temmuz 1878 'de, Almanya'da Berlin Andlaşması yürürlüğe girmiştir ${ }^{38}$.Ruslar ile sınır kesimi de yapılmış ve Horasan Sarıkamış arasındaki Han Suyu vadisi iki taraf arasında kalmıştı. Ruslar, ön barış ve asıl barış zamanında, halka ve komutanlara olgun davrandılar. Musa Paşa da, bunlar arasında idi ve belki de Loris Melikov ile eski dostluğun tezahürü idi. Onlar sınır gerisine çekildiklerinde Musa Paşa da epey rol oynamıştı.

8 Şubat 1878 ile 7 Eylül 1878, Erzurum için işgal gönlerinin yaşandığı zamandır. Osmanlı yöneticiler arasında Ruslar ile ilişkileri Musa Paşa devam ettirmiştir. Böylece taraflar arasındaki Fransızca anlaşmalar, Musa Paşa dolayısıyla Rusça sürdürülmüştü.

Sonunda, Ruslar törenle yöreden ve kentten ayrıldı. Musa Paşa IV. Ordûy-ı Hümâyûndaki görevine Erzurum'da kalarak devam etti.

1878-1888 arasındaki on yıl içinde de Musa Paşa, barışın sağladığı imkânlarla son zamanlarını Erzurum'da geçirdi. Bu dönem hakkında kaynaklardaki bilgi oldukça azdır.

\section{Şeyh Şamil Oğlu Gazi Mehmed Paşa}

Şeyh Şamil, Dağıların ve Kafkaslıların efsanevi kahramanıdır. Moskof veya Urus denilen ananevi gâvurlara karşı büyük mücadele vermiş ve Kafkasların bağımsızlık yolunda önderi olmuştur ${ }^{39}$. Bu büyük kahraman hakkında birçok eser kaleme alınmıştır. Muhammed Tahirü'l Karakhi tarafından yazılan "İmam Şamil'in Gazavâtı, dilimize Tarık Cemal Kutlu tarafından aktarılmıştır ${ }^{40}$. İmam Şamil, batı dünyasında da,

\footnotetext{
${ }^{35}$ Allen, a.g.e., s. 513.

${ }^{36}$ Allen, a.g.e., 196.

${ }^{37}$ Mahmud Celalleddin Paşa, a.g.e., 575-581.

${ }^{38}$ Allen, a.g.e., s. 196, Mahmud Celalleddin Paşa, a.g.e., s. 684.

${ }^{39}$ Şeyh Şamil ve Çevresi için bkz: Muhammed Tahirü'l- Karakhi, Imam Şamil'in Gazavatı, çvr: Tahirü'l-Mevlevi, hzl: T.C. Kutlu, İstanbul 1967.

${ }^{40}$ A.g.y.
}

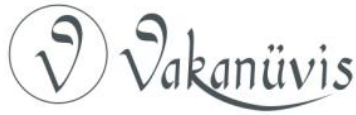


birçok araştırmaya konu olmuştur. John F. Baddeley örneği verilebilir. "Rusların Kafkasya'yı İstilası ve Şeyh Şamil" adını taşıyan araştırmada konu ile ilgili birçok Rusça ve İngilizce araştırma da belirtilmektedir. Sedat Özden'in akıcı çevirisi de İmam Şamil hakkında güncelliğini korumaktadır ${ }^{41}$.

Basiret Gazetesi ${ }^{42}$ Mehmet Bey'in İstanbul'dan ayrılışı ve doğuya, Erzurum taraflarına IV. Ordû-ı Hümâyûn'a katılışını "... Daha sonra 1000 kadar süvari ve piyade Çerkes Dilâverleri ile Unkapanı İskelesi'nden vapur-ı mahsusa ile 17/30 Mayıs 1292/1877 günü Trabzon'a hareket etmiştir. Bab-ı Seraskerî'den çıkısında meydanda bir tabur Asakir-i Şâhane dizilmiş: Mızıka çalınarak selamlanmıştır. Aynı şekilde İskele'ye kadar uğurlanmıştır" diye haber vermektedir. Yine aynı gazete, İstanbul'dan hareketinden önce de II. Abdülhamid tarafından kabul edildiği, bir süre görüşüldüğü ve iznini alarak, huzurundan ayrıldığını da yazmaktadır. Trabzon, Gümüşhane ve Bayburt yolu ile Erzurum'a ulaşan Şamil oğlu Mehmed Paşa, İstanbul Kapısında askeri tren ile karşılanmıştır. IV. Ordu Komutanı Ahmed Muhtar Paşa tarafından karargâhta huzura kabul edilmiştir ${ }^{43}$.

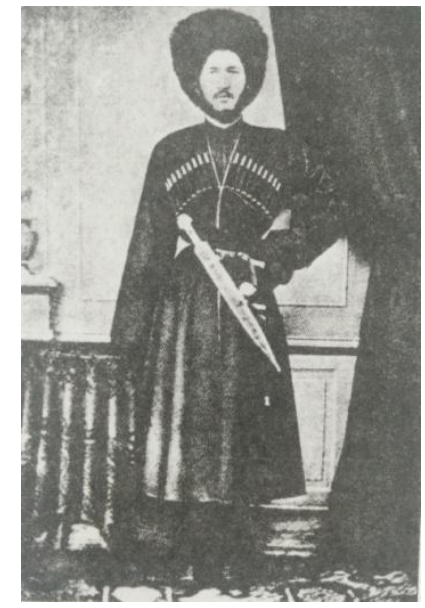

\section{Gazi Muhammed Paşa (Kaluga-1862)}

\footnotetext{
${ }^{41}$ Baddeley, a.g.e, birçok yerde.

42 Basiret Gazetesi, no: 224317 Teşrin- evvel 1293/1877, 1.

${ }^{43}$ Mezar taşındaki tarih ile aynılık görülmüyor. Ama hicri tarih için miladi karşılık $1888 / 1889$ olmalı.
}

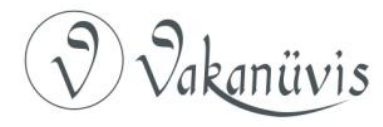


Gazi Mehmed, Ordûy-ı Hümâyûn'da ilgililer ile görüştükten sonra Ruslarla yapılan savaş sahasında yerini aldı. Bu arada, Hasbulat Bey'in kardeşi Musa Paşa ile de görüşmüştür. Kafkasya'da vaktiyle sürdürülen mücadele, şimdi de Erzurum ve doğusunda devam ettirilmiş olunuyordu. O'nun bazı etkinlikleri Ordu Komutanı Ahmed Muhtar Paşa'nın hatıratında şu satırlarla ifade edilmiştir: " Gazi Mehmed'e, "Paşalığı içine alan feriklik aşaması tevcih edilmişti. Erzurum'un doğusunda, Şüregel Düzü'ndeki, Ani harabesinin karşısındaki Alacadağ"a imdad olarak gönderildi. Yahniler'deki çatılmada Osmanlı Ordusunun sağ kanadında idi. Bu civardaki Kızıltepe'ye ilk çıkan atılır, Şeyh Şamilzâde Ferik Gazi Mehmed Paşa'nın Dağıstanlıları idi. Mehmed Paşa'nın kayını Dağıstanlı Kolağası Mehmed'e güveni fazla idi. Ahmed Muhtar Paşa'ya nazaran, Kolağası Mehmed Bey, her türlü yeteneüe sahip kimse olup, yiğitliği Ruslarca da söylenmiştir. Düşmanın Şatıroğlu tepesindeki harekâtına dair birçok önemli ve hayati bilgiyi bu Dağıstan'ı ifa etmiştir. Keza, Gediklerdeki çatışmada, Dağıstan atlıları, Çerkes Mirliva Musa Paşa'nın da beğenisini kazanmışlardı. Osmanlı ordusu kademeli geri çekilişte, Mehmed Paşa da askeri ile Köprüköyü'ne dönüp, mevzilenmişti. Çoban Köprüsünün hemen yanı başında, Ordu Komutanı "Meşveret Meclisi" yapmıştı. Katılanlar arasında İsmail(Kürd), Mustafa Savfet, Kaptan/Paşa Mehmed (Prusyalı) ve Gazi Mehmed Paşa da bulunmuştu. Durumun ruslar karşısında pek iyi olmadığı hakkında ortak düşünce hâsıl olunca, Ahmet Muhtar Paşa'nın da oluru ile kuvvetler Deve Boynu'na çekilmiştir".

Buna benzer hadiseler de Kitâbette bulunan ve her zaman Ahmed Muhtar Paşa'nın yanında bulunan Mehmed Ârif de, de tekrarlanmıştır. 


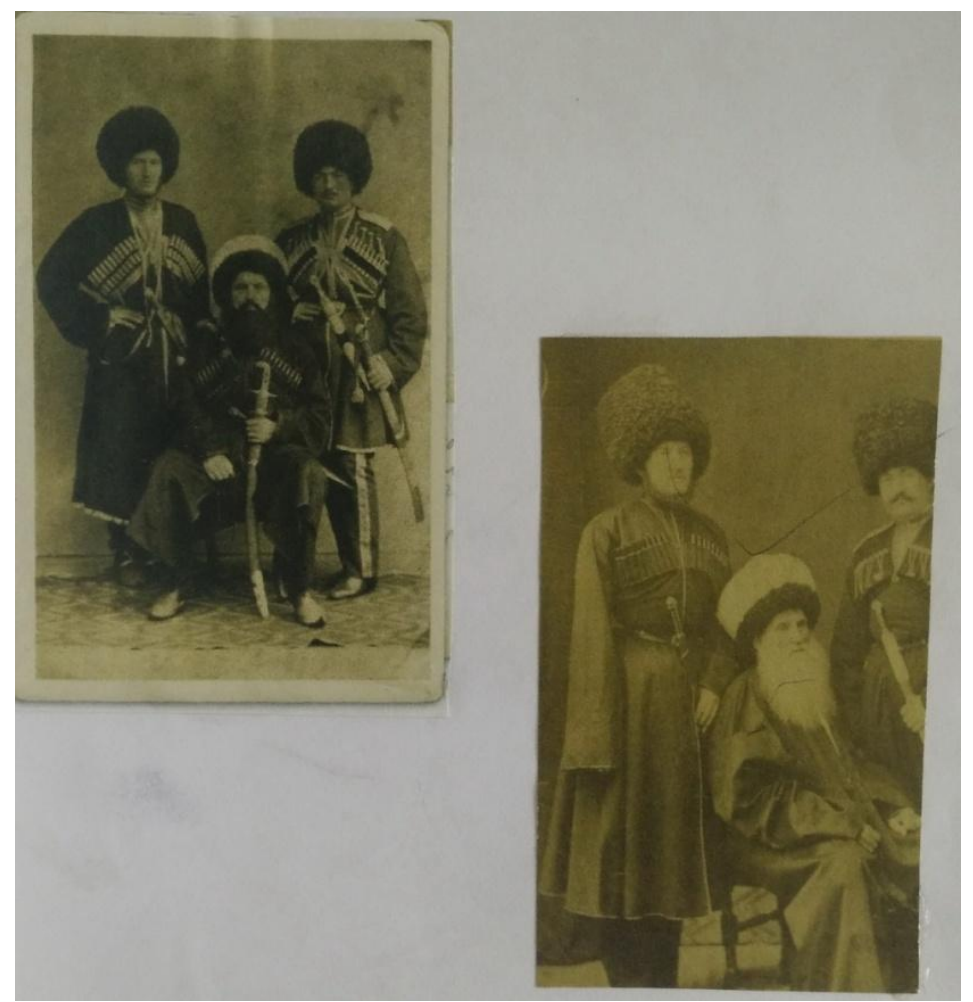

Gazi Mehmed (Kafkas Kahramanı, Şeyh Şamil'in oğlu

\section{Musa Paşa'nın Erzurum'da Ölümü (1888/1889)}

W.A.D. Allen (1901/1973), Kafkasya ile ilgili meşhur eserinde Musa Paşa için " Musa Kundukhov paşa 1889'da Erzurum'da öldü" denmektedir. Yine paşanın "hatırat"ını yayınlayan Ali Kantemir, 1939'da, benzer ifade ile şunları yazar" Musa Paşa'nın enerjisi kurulmuştu. Ordudan çekildi ve ömrünün geri kalan kısmını Erzurum'da sükûnetle geçirdi.1889'da da orada öldü. Mezarı Narmanlı Câmiinde kardeşi ve Şamil'in eski silah arkadaşı Hasbulat Beyinkinin yanındadır. Fakat Ruslar bu ölüyü de rahat bırakmadılar. Büyük Harp'de (1916) de Erzurum'u tekrar işgal ettiklerinde, cami ve mezarı yıktılar. Bu hayâsızca hareket bu kanlı dönemin son sahnesi oldu. Sonra Bolşeviklik

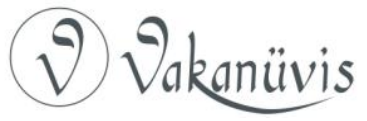


geldi. "keza, paşa hakkında önemli bir makale kaleme almış olan Tarık Cemal Kutlu'da, 1889 tarihini kabul etmiştir. Mezar kitabesinde verilen hicri tarih 1306'dır. Bu da 5 Aralık 1888 Pazartesi - 27 Ağustos 1889 Salı'ya İsabet etmektedir. Benim ve sonraları Yrd. Doç. Dr. S. Tozlu'nun tesbit ettiğimiz tarih H. 1306dır. Bu da yukarıdaki zaman dilimine tekabül etmektedir ${ }^{44}$.

Hemen bütün kaynaklar, o'nun törenle Erzurum'da, Narmanlı camiinden kaldırılarak, güney taraftaki duvar yakınına (dibinde) toprağa verildiğinde fikir birliği halindedir. Ben de aynı şeyleri görmüş ve yazılı hale getirmiştim.

Bu tarihi olayın geçtiği Narmanlı Camii I. Sultan Mahmud döneminde, 1738'de, Hacı Yusuf tarafından inşa ettirilmiştir. Kendisi Erzurum kazalarından Narman'dan olduğu için de daha çok kendi ismi ile değil, memleketi ile tanınmıştır. Daha sonra cami etrafında Narmanlı Mahallesi teşekkül etmiştir. Burası Erzurum Kalesinin önemli kapılarından Tebriz Kapısı dışında olup, Her zaman hareketli bir yaşama sahne olmakta idi. Emir Şeyh ve Çifte Minarelerinde civarında olan Narmanlı Cami'nin mütevazı bir bahçesi dolaysıyla bir haziresi bulunuyordu.

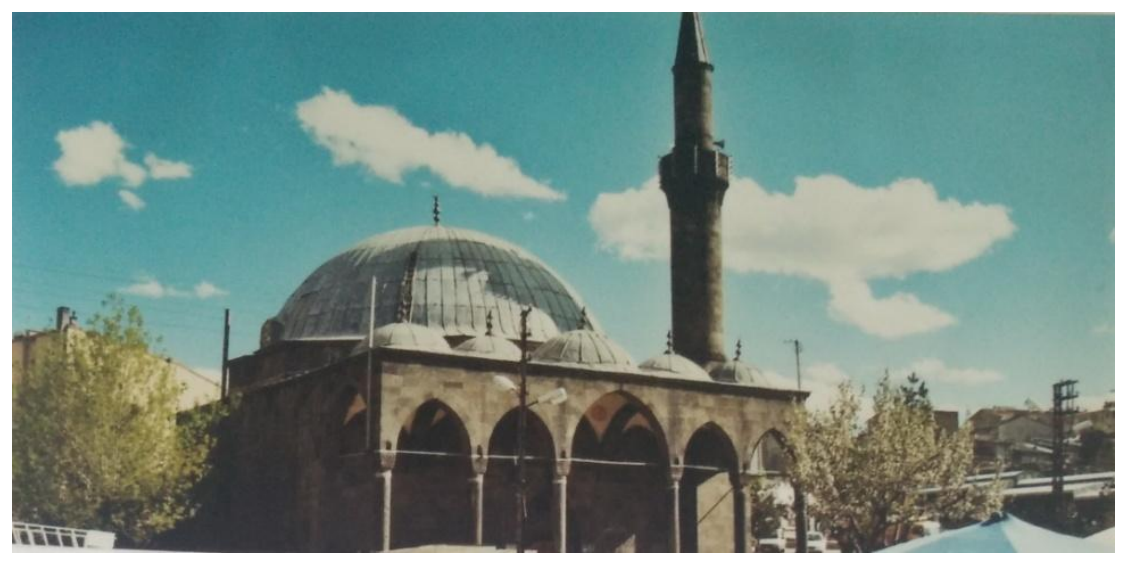

Erzurum, Tebriz Kapı'da Harmanlı Câmii

${ }^{44}$ Bkz: not 43.

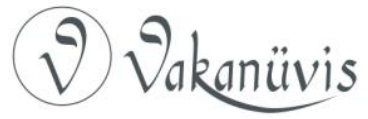




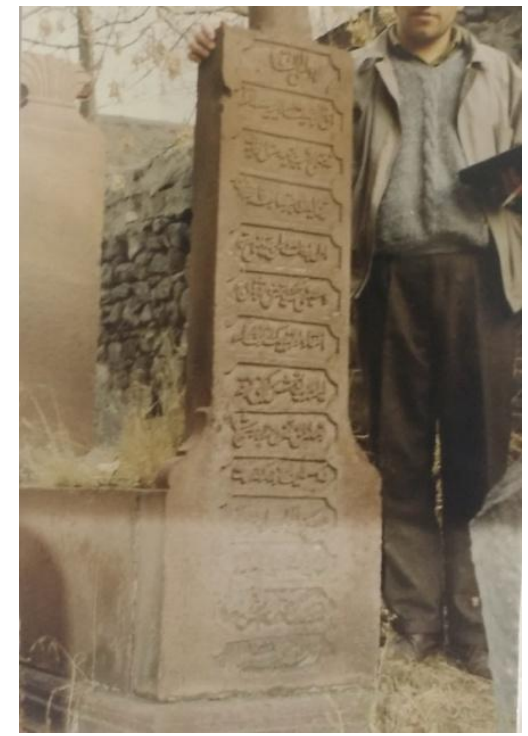

Yrd. Doç. Dr. Selahattin Tozlu Musa Paşa Mezarını İncelerken
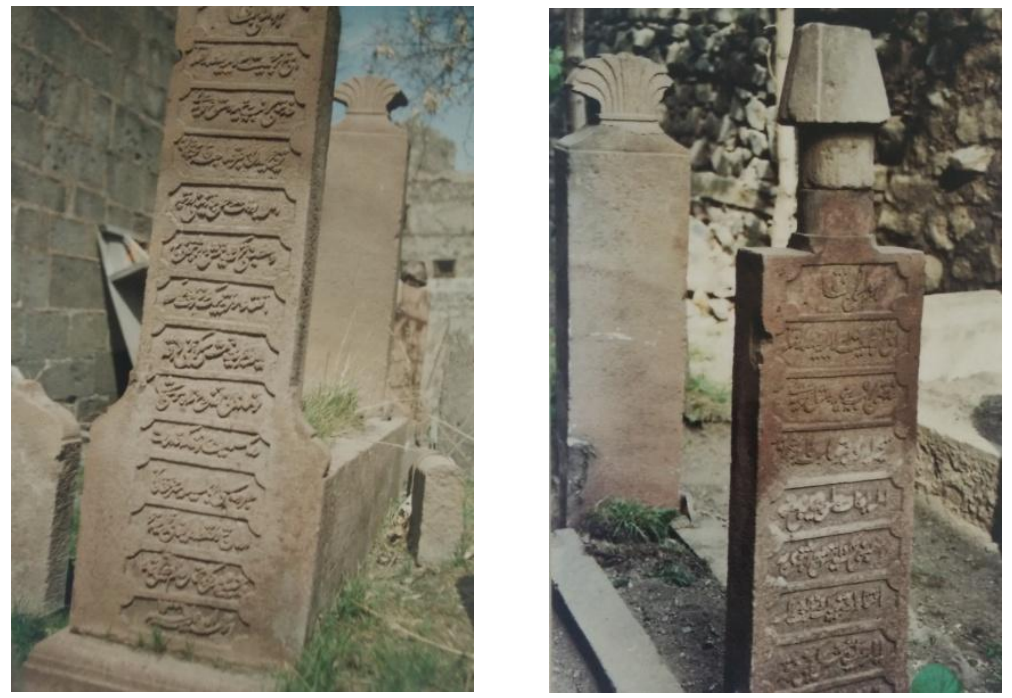

Erzurum Tebriz Kapı Çifte Minareler Doğusunda Narmanlı Camii'ndeki Musa Paşa Mezarı

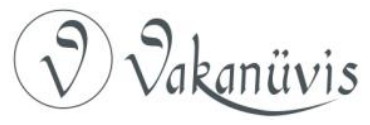



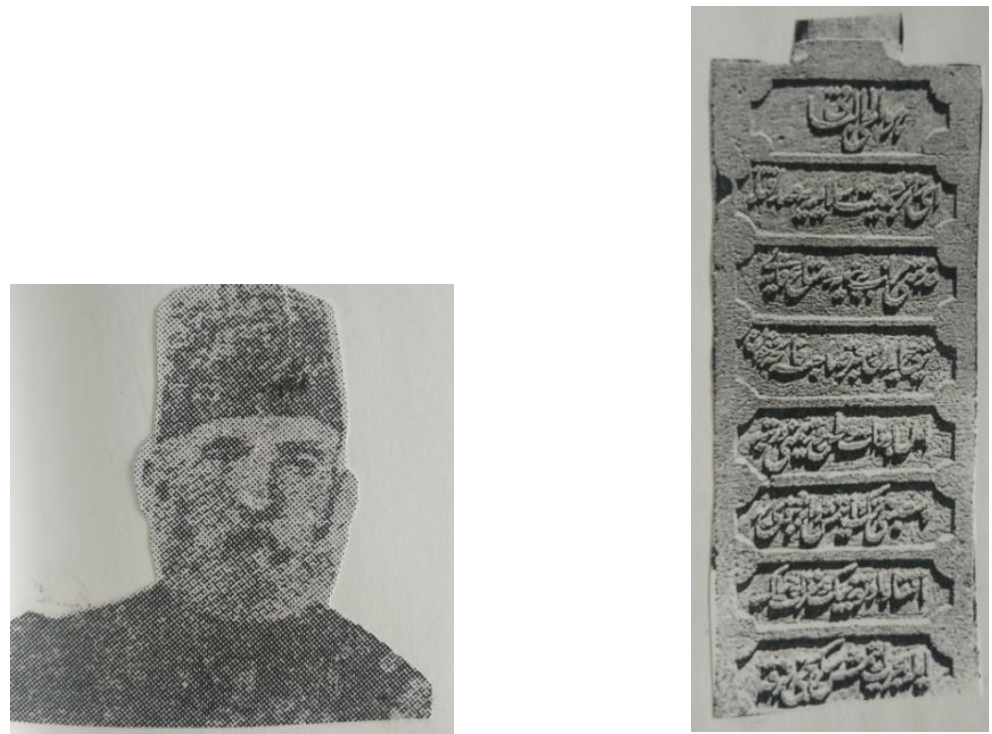

$$
\begin{aligned}
& \text { موالحّ" الباقى }
\end{aligned}
$$

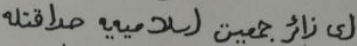

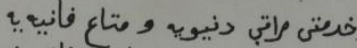

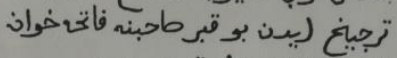

$$
\begin{aligned}
& \text { (ول بو خان وطن قرئن ورتبه }
\end{aligned}
$$

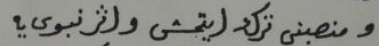

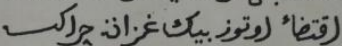

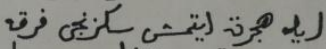

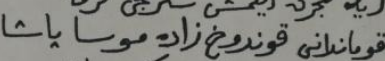

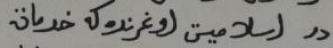

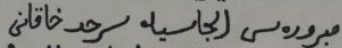

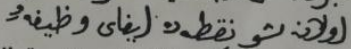

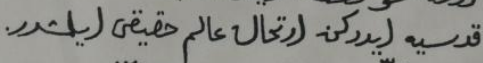

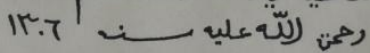

Hüve'l Hayyư'l Bâki

Ey zâir cem'ilyyet-i islâmiyeye sadakatla hidmeti meratib-i dûnyeviyye ve metâ-ı fâniyeye terci iden bu kabir sâhibine fâtihahan ol. Bu zât, vatan-ı kadimini ve rūtbe ve mansıbını terk itmiş ve eser-i nebeviye iktiza otuzbin guzzât-ı Cerakisise ile hicret etmiş sekizinci fikra kumandanı Kunduh-zâde Musa Paşadır. ư̆rundaki hidemât-ı mebrüresí ilcâsıyla serhadd-i Hakanî olan şu noktada ifây-i vazife-i kudsiyye iderken irtihâl-ı âlem-i hakiki eylemișdir.

Rahmetullahu aleyh. sene 1306

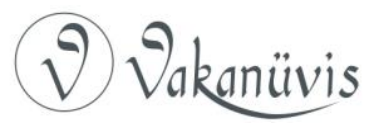




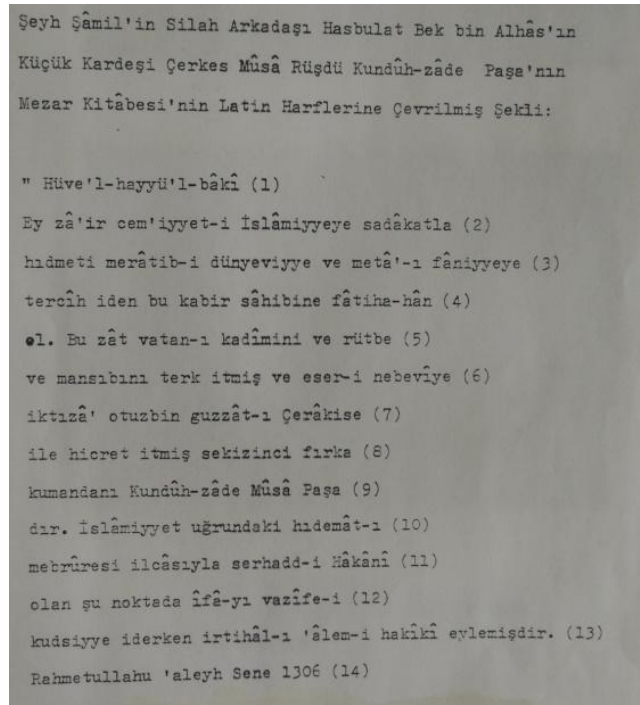

\section{Musa Paşa'nın Mezarı'nın Kitabesi}

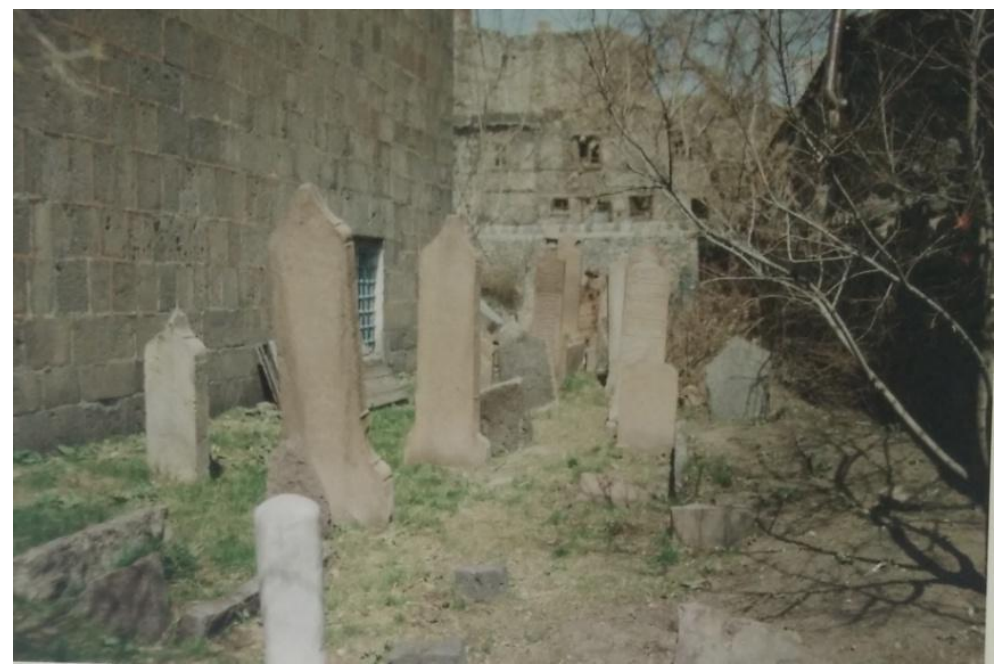

( ) V Vakaniuvis 


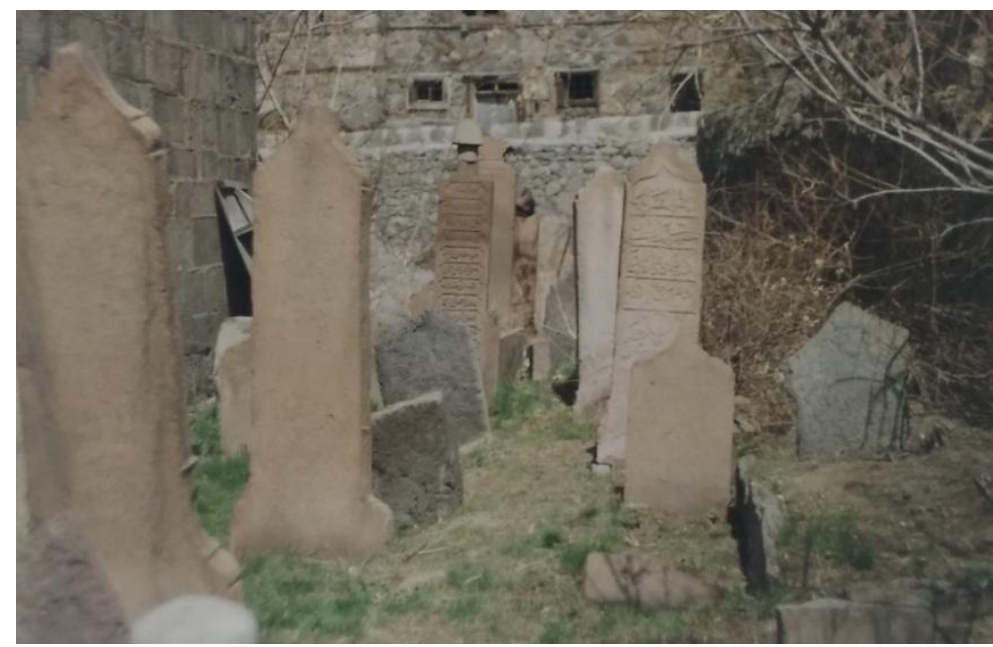

Narmanlı Camii'nde Musa Paşa Kabri

\section{Bekir Sami Bey}

Milli Mücadele başlarında üç Bekir Sami vardır ${ }^{45}$ Ikisi Kafkas asıllı bir de Erzurumlu, Aha Köylü Bekir Sami'dir. Kafkaslı olanlar Bekir Sami Kunduk ve öbürü de yine Milli Mücadele saflarında yer alan Bekir Sami Günsav'dır. Musa Paşa'nın oğlu olan Bekir Sami büyük göçte babası ve amcası ile Osmanlı tarafına geçmiştir. Önce Erzurum'da, sonra da Tokat'da Batmantaş Köyünde hayatını devam ettirmiştir. O'nu üzen ilk önemli hadise ise Şeyh Şamil'in Yandaşı amcası Hasbulat'ın Erzrum'da hayata veda etmesidir. Diğer kardeşi ise Murad Bey'dir. Öğrenim görmesi için İstanbul'a gönderildi. Galatasaray/ Mekteb-i Sultani'yi başarı ile bitirdikten sonra, yurt dışına çıkmış ve Paris'te yüksek öğrenim görmüştür. Ülkenin artık çöküşe doğru gittiği bir zamanda Hariciye mesleğini seçmiştir. Illk görev yeri Petersburg'tur. Bunu Tebriz, Sina, Kirmanşah, Malta, Mesine gibi yerler takip etmiştir. Libya'da Batı Trablus'ta Mektupçuluk yapmış ve böylece Hariciyeden, Dâhiliyeye geçmiştir. Halep Valisi iken İttihad ve Terakki'nin ilk üçlerinden Cemal Paşa ile yetki anlaşmazlığına düşmüş, görevi bırakarak, göç sonrası

${ }^{45}$ M. Ünal, Kurtuluş Savaşında Çerkeslerin Rolü, İstanbul 1996, 118-171.

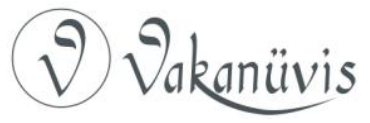


baba yurdu Tokat'taki Batmantaş'a, Köyüne çekilmiş ve bir süre çalkantılı hayattan uzak kalmıştır. Çiftlikte sade bir hayat sürerken, Mondoros Mütarekesi yapılmış, yurdun düştüğü kötü durumu siyasal olarak düzeltmek için de Milli Ahrar Parti'sine dâhil olmuş ve kurucu grupta yer almıştır. Fransızca ve Rusça'ya hâkim olan Bekir Sami Bey, Anaolu'daki hareketi de bu sırada yakında takip etmiştir. Yeni kurulmakta olan Müdafa-i Hukuk Cemiyeti bünyesinde çalışmış ve M.Kemal tarafı bir tutum içine girmiştir. Erzurum Kongresi sonrası Sivas'da, 4 Eylül 1919'daki kongresinde, dost grubu içinde olmuş ve Hey'et-i Temsili üyeliğine de seçilmiştir. Bu arada İstanbul- Sivas uzlaşmasını sağlamak için harekete geçmiş, Salih Paşa ile vâki görüşmlerde etkin rol oynamıştır. İstanbul'da toplanacak olan Meclis-i Mebusan-ı Osmanî́ye, Amasya'dan seçilmiştir. 1919-1920yılının bir bölümünde ìstanbul'da temsil görevini devam ettirmiş, bu sırada Meclis'deki olumsuz durum üzerine, M.Kemal'in çağrısı üzere Geyve yolu ile Ankara'ya geçmiştir. TBMM'nin oluşumunda yine aynı yöreyi temsil etmiş ve 8 Nisan 1920 sonrası da bozkırdaki Ankara'da, çalışmalarını devam ettirmiştir. icra vekillerinin teşkili $v$ vekilliklerin tespiti sırasında da yabancı dil ve dış işlerindeki deneyimi de göz önüne alınarak, 3 Mayıs 1920'de, ilk Hariciye vekili seçilmiştir. Rusya ile ilişkilerin geliştirilmesinde, görüşlerini Ankara'ya bildirmiş, aynı yıl sona ererken yurda dönmüştür. Düzce- Bolu ayaklanmalarının artık şiddetini iyice kaybettiği bir sırada, İstanbul ve VI. Mehmed Vahdeddin, 15 kişilik idam kararı içinde Bekir Sami Bey de bulunuyordu. Şubat 1921'de yurt dışına çıktı ve Avrupa'da, Briand, sonra da Kont Sforza ile bir araya geldi. M.Kemal ve TBMM'nin niteliği ve isteklerini yakın bir çevreden oluşu nedeni ile iyi bir şekilde anlattı. 1922'de, rahatsızlığı için Avrupa'da tedavisine dair bir izin çıkarttı. TBMM'nin ikinci döneminde de bu defa Tokat'tan milletvekili seçildi. umhuriyetin ilanı sonrası çok partili sistemde yer aldı. Terakkiperver Cumhuriyet Fırkası'nda göze çarptı. Suikast ithamı ile muhakeme edildi Temmuz 1926 'da beraat etti. Siyasetten uzak durmak ve kendini daha saygın bir duruma getirmek için Tokat'taki Çiftlikte, sonra İstanbul'da sivil hayatını devam ettirdi. Cumhuriyetin onuncu yıl hazırlıkları sırasında İstanbul'da hayata veda etmiştir $^{46}$ Yakın çevresinde Kundukzâde diye biliniyordu. 1934'de

${ }^{46}$ TBMM Albümü, Ankara 1994, s. 2. Buradaki ölüm tarihi 16 Ocak 1933'tür.

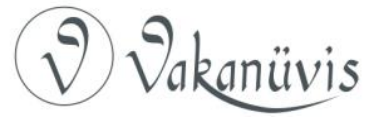


ise ailesi, resmen Kunduh soyadını almıştır. "Bekir Sami Bey'in "biricik kızı" Nimet Kunduh idi. İstanbul gazetelerinden birinde verilen vefat ilanı şöyledir:

Erzurum Müdafii Müş'ir Musa Paşa'nın torunu, Sadrazam Kamil Paşa'nın torunu, merhume Akile Kunduh'un görümcesi, Atatürk'ün yakın arkadaşı eski Dışişleri Bakanlarından Bekir Sami'nin biricik kızı, Is Bankası meclis idare azalanından merhum Şevket Kunduh'un tek hemşiresi, heykeltraş Mine Sunar'ın çok sevgili halası, Soroptimist Kulübü eski Başkanı Türk Kanser Araştırma ve Savaş Kurumu gönüllü grup başkanı eşsiz insan;

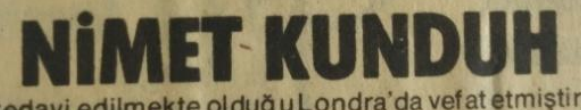

tedavi edilmekte olduğ L Londra'da vefat etmiştir.

Teessürle duyurulur.

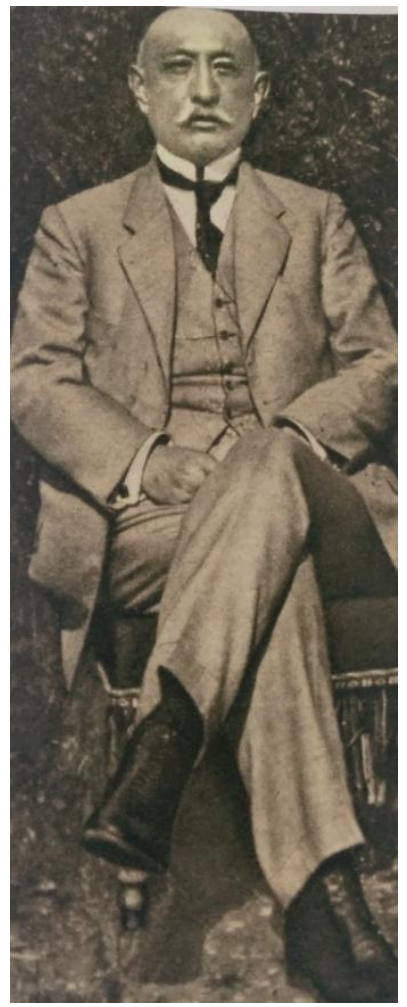

Bekir Sami Bey

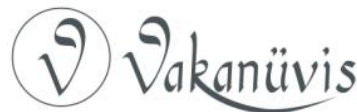




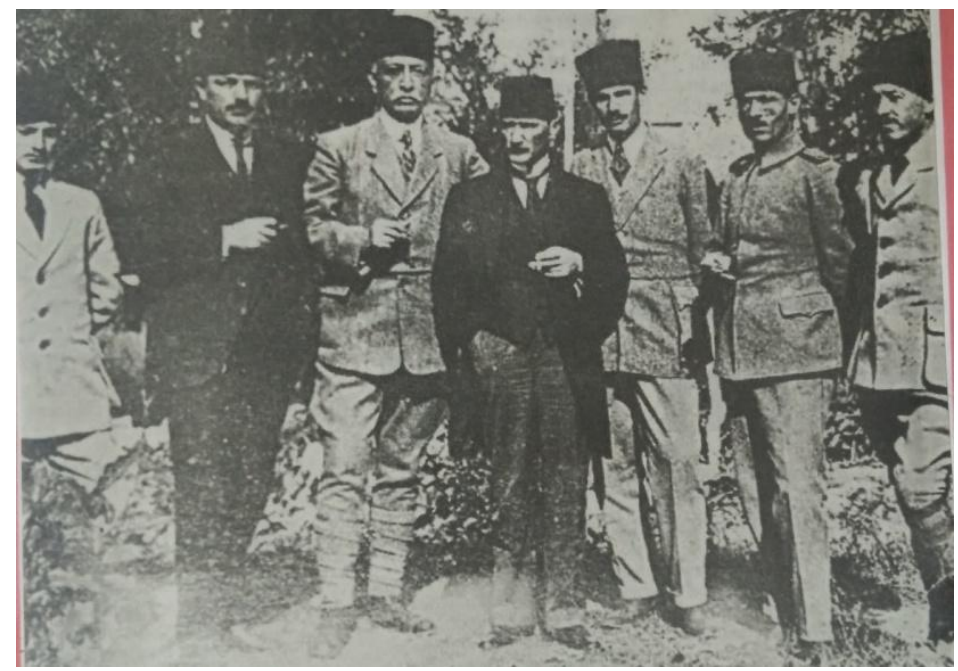

Rauf Orbay, Bekir Sami, Mustafa Kemal Sivas'ta (Eylül 1919)

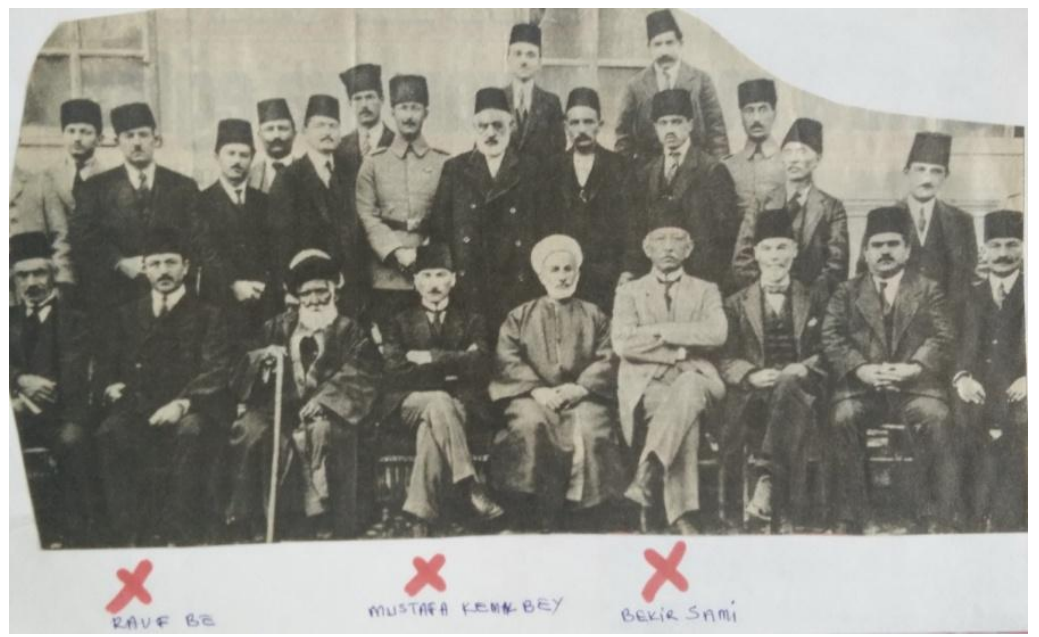

Musa Paşa'nın Oğlu Eski Dışişleri Bakanı Bekir Sami Bey

(V) Vakanüvis 


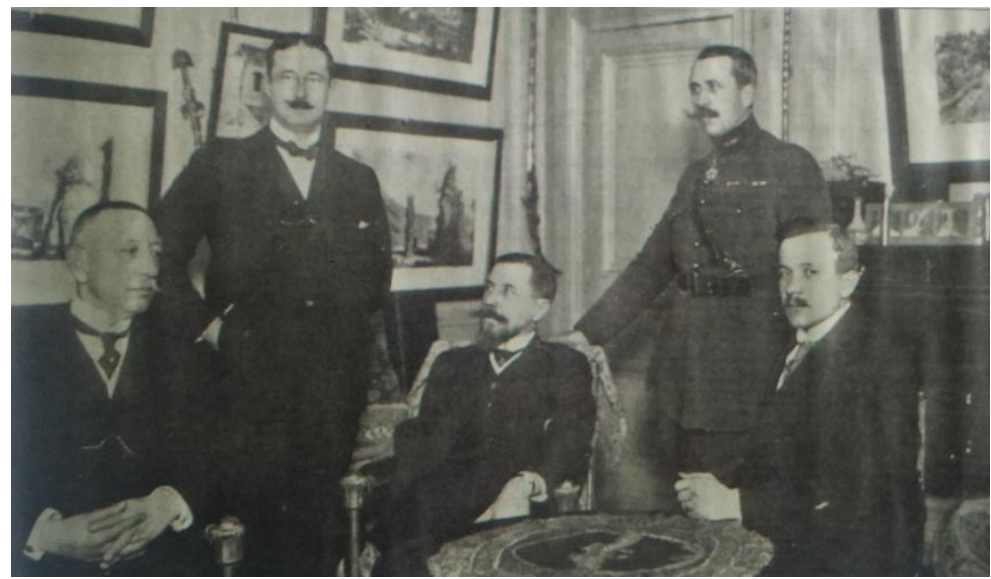

\section{Bekir Sami, Hüsrev Gerede, Zekai Apaydın (Londra'da)}

Bekir Sami, Şevket vs. yakınlar da Paşa'nın ölümünden sonra Osmanlıların hizmetinde bulunmuşlardır. Bekir Sami temas edildiği üzere Cumhuriyet'te de yeni devletin, Türkiye'nin vatandaşı olarak Batmantaş ve çoğu zaman İstanbul'da yaşamıştır.

Erzurum'da, Rauf Bey'in valiliği 1895-1903 tarihleri arasındadır. İstanbul yazışmalarında, bir Kunduk'lunun varlığından haberdar olmaktayız. 19 Teşrin-i Evvel Sene 1314 tarihli bir belgeden bu husus ifade edilmekte ve şunlar yazılmaktadır ${ }^{47}$ :

"Esasen kendisi Ferik Musa Paşa merhumun akrabasından ve Ümera-i yüzbaşı-ı evveli Mahmud Rıza Bey kullarının Orduy-ı Hümâyûn'un inhası vech ile Kolağalığa terfiî ile....".

Belgeden anlaşıldığına göre Mahmud Rıza Bey, akrabasındandır. Kunduklara mensuptur. Türkiye'ye göçten sonra o da herkes gibi o da teamüle uyularak Çerkes diye tanımlanmaktadır. Sadık Çerkeslerin Beylerinden olduğuna da dikkat çekilmektedir. IV. Ordûy-I Hümâyûn'un 22. Süvari alayı, 3. bölüğü önyüzbaşısı rütbeli olup, Erzurum'da ikamet etmektedir. Şimdi ise Kıdemli Yüzbaşılığa atanması uygun görülmüştür.

${ }^{47}$ Sultan II. Abdülhamid ile Erzurum Vilayeti Arasındaki Yazışmalar (1894/1906), Hzl: M. Demirel, İstanbul 2007.

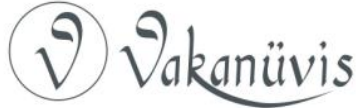




\section{Musa Paşa'nın Hatıratı}

Musa Paşa ehl-i kılıç olduğu gibi aynı zamanda ehl-i kalem idi. Rus ordusunda görevli olduğu zamanlara ait görüşlerini 1837-1865 yıllarını kapsayan hayat hikâyesini detaylı bir surette hazırlamıştır ${ }^{48}$. Ailesinden torunu Şevket Bey, elindeki dosyayı Alihan Kantemir'e vermiştir. o'da Fransızcaya çevirmiş ve böylece 1939 'da yayınlanmıştır. Hatırat, Les Memories du General Moussa Pacha Kundoukhov (1837-1865), Paris'te yayınlanmıştır. Türkiye'de ise Murat Yağan "General Musa Kundukhov'un anıları, İstanbul, 1978"adı ile tarih veya hatırat literatürüne kazandırmıştır. Esere göre Musa paşa, 1818'de dünyaya gelmiştir. Alkhas Kunduk'un ve Dölet hanım'ın oğludur. Dört kardeştirler ve Hasbulat Bey kendisinden ayrı bir yol seçmiş ve İmam Şamilin hizmetine girmiştir. Askerliğe dâhil oluşu 1837'dir ve göreve süvari subayı olarak başlamıştır. Hayat arkadaşı olarak Kubatı hanımı seçmiş Arslan ve Bekir Sami Beyler de çocukları olmuştur. Bu sıralarda İmam şamil Kafkas hareketinin lideri olarak ortaya çıkmış ve Çeçenlerin birçoğu kendisine katılmıştır. Musa Paşa eserinin girişinde ve sonrasında İmam Şamil ve Dağlılar konusunda kendi açısından önemli bilgiler vermektedir. Bu arada Hasbulat Bey de kendisine ayrı bir yol çizmiş ve İmam Şamilin yanında yer almıştır. Kardeşi ile görüşmesine de yer veren Musa Paşa, kendine göre daha akılcı malumat vermekte ve kendisinin durumuna da işaret etmektedir. Şamil Galakha'ya geldiğinde, Vladikafkas Bölge Komutanlığına da Baron Vrevski tayin edilmiştir. Prens Vorontsof'un görev değişikliği üzerine de Generel Muraviev, General Barianinsky Kafkas'da ordu komutanı olmuştur. Rusya, Musa Paşa'yı da bu sırada Çeçen Mıntıka Komutanlığına getirmiştir. Vazifesinin ilk sıralarında Çeçenlere bir de mektup yazmış, Rusya'nı Çeçenistan işgaline de müdahale edememiştir.

Musa Paşa, Çeçen politikası nedeni ile buradaki görevinden ayrıldı. Bu arada Terek'deki dağlılar hakkında bir rapor kaleme almış, ilgililere iletmiştir. Lori Melikov, Musa Paşa'nın yakından tanıdığı Gürcü asıllı Rus subayı idi. Bu arada İstanbul'a görevle gitmiş Rus üniforması ile Osmanlı ileri gelenleri ile dostane bir görüşme yapmıştır. Böylece Rusların da izni ile Çeçenlerin toplu göçü için ilk adımlar da onun sayesinde atılmıştır. Fakir göçmenler de göz ardı edilmemiş ve az sonra

${ }^{48}$ Les Memories ..., s. 9.

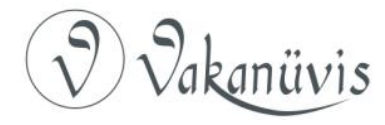


da tarihi göç başlatılmıştır. Kendisi de ordudaki vazifesine son vermiştir. Vladikafkas'tan devlet-i Aliyyye-i Osmaniye'ye hareket edilmiştir. Yolculuk sırasında Prens Greguar Orbeliani ve bazı Gürcü prensleri ile de görüşmüştür. Bu arada Musa Paşa, Çeçen Mayri Biybulat hakkında da kısa bilgi vermektedir. Hatıratın son kısmaında ise Musa Paşa, Kafkas Orduları Kurmay Başkanı A.P Kartsef'e mektup kaleme almış ve son durum hakkında bilgi vermiş̧ir. Bu Rus Subayı, Musa Paşa'nın okul sıralarından beri yakın dostu idi. Mektup Viladikafkas'tan 25 Ağustos 1863 'de yazılmıştır. Yani, Asetin ve Çeçen göçü öncesine aittir. Alihan Kantemir gibi eserin sonunda Z.Avalichvili'nin de önemli ve Gürcü görüşünü dile getiren yazısı vardır.

Böylece bir askeri yetkili olan ve insanlarını Müslüman bir ülkeye taşımış olan Musa Paşa, üstüne düşen görevi ikmal etmiş olmaktadır. Eser ve içeriği hakkında, hatıratın giriş kısmında yer alan ve Fransızca "Malheur aux Vaincus" söylemi ile sona eren yazısında da "Les Memories ..."genel bir özetini verdiğini de işaret edelim. 


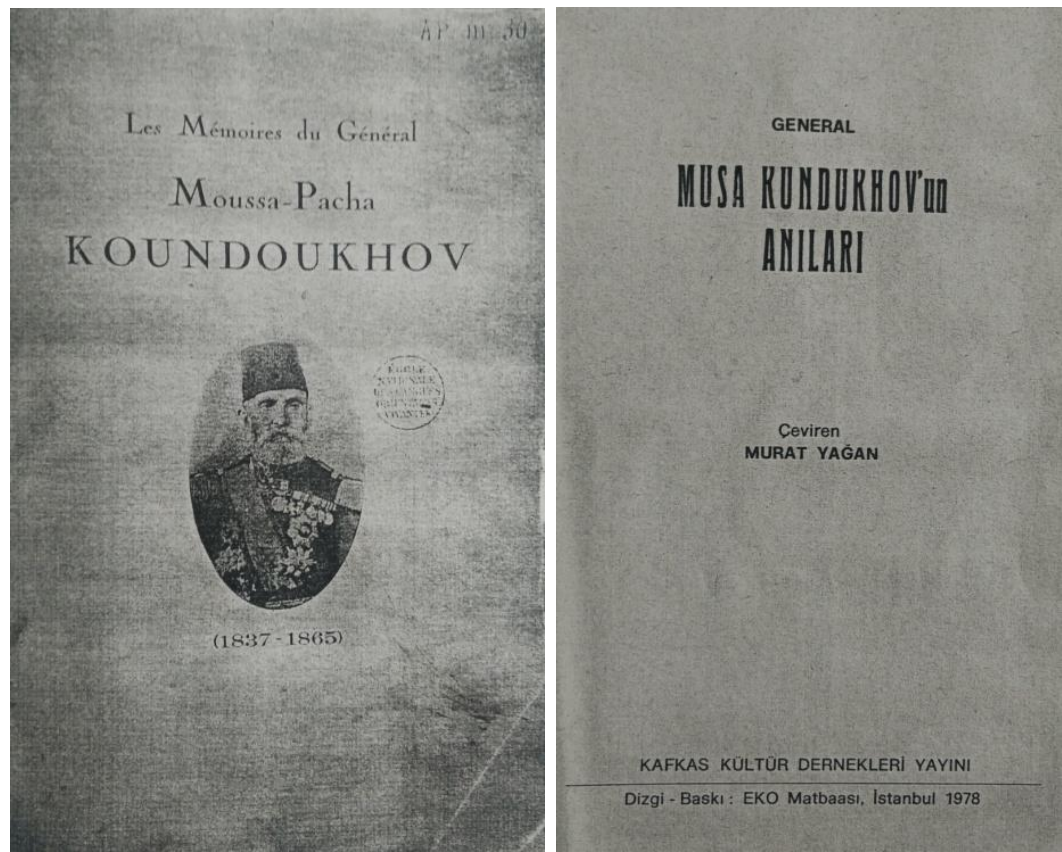

C Kafkasya'nın bağımsızlık savaşları sırasında, yani sıkıntılı ve meşakkathı bir devrede yaşamış ve icraatta bulunmuş olan Kunduh Musa Pașa'nın adı bugüne kadar Kuzey Kafkas halklarının ve eski Kafkas göcmenlerinin anılarında kalmıştır.

Bununla beraber, hakkında söylenen, genellikle gerçek diȘı rivayetlerle Tiflis arşivlerindeki bilgiler, Kuzey Kafkas kavimlerinin tarihinde silinmez izler bırakmıș olan bu kayda değer zatın kișiliğini ve calıșmalarını yeteri kadar aydınlatmamaktadir.

Şayanı memnuniyet fırsatların yardımıyle, bugün bizzat Musa Pașa tarafından bırakılmıș olan ve Cerkeslerin kitle halinde Türkiye'ye hicretile sona eren istiklal muharebeleriyle muğlak bir halde olan o devirlerle kendi șahsının bir araya getirlak bir haide olan o devirhul vesikalar elde ediyoruz.

Musa Kundukhov Pașa'nın, harp ve intilallerden mucizevi bir sekilde kurtarılmıs olan ve torunu Sevket Kundukh tarafından basılması için bize lutfedilen bu eseri, Kafkas tarihi icin en kıymetli bir vesikadır.

Bu eser ve Musa paşanın oğlu sabık Türkiye Hariciye Veyaptığımız muhtelif mülâkatlar, bize Kafkili Bekir Sami beyle yaptigi adamlarından birinin şahsiyet ve kasya'nın en șayanı dikkat adamkan imkânını veriyor.

faaliyetini tanımak imk Busların gelmesinden önce, tarihte Ta'uMusa Kundukhov Ruslarn gerag ile Fiagdon arasında uzari veya Taur'dali diye anilan ve Terek Taga'ur-Aldar (Feodal-Tinan doğu Osetya'yı idare eden bir Taga'ur mıntıkasının gü-

mar ve zeamet) ailesine mensuptur. Ta'ur mintikasnin gü-

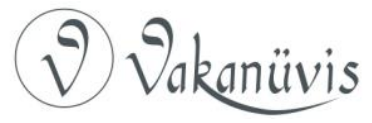


ney sınırını, Kafkas dağlarının doruk çizgisini izleyen Gürcüstan kırallığı teșkil ediyordu. Bu mıntıka Gürcü askeri yolunun, Ta'urların korudukları ve denetledikleri ve yolculardan geçit ücreti aldıkları, kuzey kısmını içine alıyordu.

Musa Pașa'nın babası Alkhas Kundukhov ile annesi Dölet Dudar Hanım, Sanib köyünde oturuyorlardı. Musa burada 1818 de doğdu.

Musa'nın ailesi kalabalıktı : Dört cocukları vardı: $\mathrm{Hacı} \mathrm{Ha}-$ murza, Hazbulat, idris ve Afako kardeșler.

Musa Kundukhov Rusyanın, tam Gürcüstanı kendisine kattığı 1818 ve Kafkasya'nın bütün müslüman kısmının fethine hazırlanmağa bașladığı zaman dünyaya geldi.

Kafkas istilasının metodlarından biri, özellikle bașlangıcta, eğitim ve öğretime ait olanıydı. Bunun için Carın emrile nufuzlu Kafkaslıların cocukları hükümet hesabına öğrenim yapmak üzere Moskova ve Petersburg'daki askeri okullara gönderiliyordu. Özel memurlar, aileler yanında iyi sözler ya da tehditlerle cocuklarını (beyaz Carın) okullarına gönderilmeleri için icraatta bulunuyorlardı. Böylece nufuzlu Kafkasyalıların Rus askeri okullarında öğrenim yapan cocukları, Rus hükümetinin elinde adeta bir rehin vazifesini görüyorlardı. Bunun için o devrin tarihinde bunlara "emanetler" adı verilmiști.

Emanetler savaș tutsaklarından farklı olmayan özel bir rejim alṫında idiler. Bu bedbaht cocukların eğitimi cahil ve kaba gediklilerin eline bırakılmıștı. Bunların metodları ise genc Kafkaslıları genellikle Rus düșmanı yapıyordu.

Iște böylece emanet sıfatile o zaman on iki yașında olan genc Musa Kundukhov Petersburg'da Pavlov askeri okuluna gönderildi ve buradan altı sene sonra suvari subayı larak cıktı. Bir sene sonra (1837) genc subay Kundukhov Imparator I. Nikola'nın Kafkasya'da bulunması esnasında maiyetinde tercúman sifatile refakat etti.

$\mathrm{Bu}$ andan itibaren önüne, onu daha çok genç yașında general rutbesine kadar götüren parlak bir yol açılmıștı. Fakat bu șan, șeref ve saire Musa'ya mutluluk ve ruhi güvence ver- 
medi. Musa Kundukhov'un Rus ordusundaki hizmeti, Rusya ile meșhur İmam Șamil'in müdafa ettiği anavatanı arasındaki müthiș savașlarla aynı zamana rastgeldi.

Rusya Kafkasya'yı demirden bir cember içine aldı ve $M$. James Belle'e göre (Journal de residence au Caucase 1837 1838 et 1839), İngiltere'de York kontluğu arazisinin en iyi ișlenmiș kısmını anımsatan mamur bir ülkeyi yağma etmeye bașladı. Kafkasya'nın mukadderatı belli olmuștu. Her vicdanlı Kafkasyalı için bu artık bir hayat ve memat sorunundan bașka bir Șey değildi. Büyük bir kitle Șâmil'i tutuyordu, ülkede eli silah tutan kim varsa vatanî bir hamle ile bağımsızlık savașı bayrağının altına gecti.

Bu kahramanlık devrinde Musa gerçek bir dram yașıyordu. Birçok akrabalarile ve özellikle savașın, bütün Kafkasyalılar için, gürcüler ve ermeniler de dahil olduğu halde, kutsal bir görev olduğunu takdir eden kardeșleri $\mathrm{Hacl} \mathrm{Hamurza} \mathrm{ve} \mathrm{Haz-}$ bulat ile kendisini ayıran siyasal uyușmazlık manevi ve maddi durumunu gücleștiriyordu. Onlar Șamil'in ulusal ordusuna katıldılar. İmamın ateşli müritleri olarak Ruslara karșı șiddetle döğüștüler. Musa'nın kardeșlerinden biri Hacı Hamurza Ceçenistan'da 1844 te kahramanca șehid oldu.

Doğaldır ki, bu koșullar altında Musa kendi ulusuna karȘı olayların akıșı anında üstünlüklerini teslim ettiği kardeșlerine karși silah kullanamazdı. Bunun için Musa önce Oset (Kușha), sonra Ceçen askeri sancağı șefliği gibi sadece askeri - idari durumdaki ișlerle uğraștı. Oradan Varșova'ya sonra da, 1848 de Macaristan harbine girmek üzere Karakova'ya gönderildi.

Bağımsızlık savașının devam ettiği sürece Musa Kundukhov fikren Kafkasya'nın bütünlüğü temeline dayanmak üzere Kafkasya ile Rusya arasında barıș ve doğal ilișkilerin meydana gelmesi yolunda bir formül bulmayı daha akılcı gören küçük bir Kafkasyalı azınlığın arasında bulundu.

Musa, Şamil'in ve kardeșlerinin amaçlarına karșı gerçek bir sempati duyuyor ve onlara bütün kalbiyle başarılar diliyordu. Fakat bir savaș için iyi hazırlanılmamıș olduğu kanısınday- 
dı. Mert naip Ahverdil Muhammed gibi, İmam'ın kararsızlığını ve tehlikeli hatalarını eleştiriyordu. Musa'ya göre, 1845 te Prens Vorontsof'un Darginlerdeki seferinde, Șâmil Rusların tedbirsizliğinden yararlanamamıştı. Bu hatayı yapmasaydı Rus ordusu kumandanı Aleksandr ve Hesa'i bütün kuvvetleriyle beraber tutsak edebilecekti. Böylece hemen aynı hata Vladikafkas ve Nalçik'te yinelendi.

Musa bu yanılgıların sonuçlarını ve Rusların olağanüstü kuvvet ve kaynaklarını göz önüne alarak Dağlıların tarafına geçmekten cekindi. Fakat her iki muharip taraf için de kabule değer olabilecek koșullar ve yargılar bulmağa çalıștı.

Rus ordusunda ișgal ettiği yüksek mevkii, Dağlılarla olan teması, onlar üzerindeki nufuzu ve ailevi bağlar sayesinde Musa Kundukhov Şamil ile Kafkasya'daki yüksek Rus kumandanlığı arasındaki konușmalarda aracı seçildi. Maalesef bu konușmalar bir sonuca varamadı. Șamil bütün Kuzey Kafkasya'nın bağımsızlığını istiyordu. Rus kumandanlığı ise küçük Ceçenistan, Terek ve Kuban Ruslara kalmak üzere bir hudut cizmesinde israr ediyordu.

Bu koşullar içinde barıș söz konusu olamazdı ve savaş Gunib'in düşmesine ve Şamil'in tutsaklığına kadar devałn etti (1859). Bu uğursuz tarihten sonra henüz bir kaç ay geçmiști ki, Musa generalliğe terfi ettirildi. Bu suretle kendisinin, artık istila edilmiș olan ülkede asayișin temini hususunda yararlanılacağı ümit ediliyordu. Gerçekten 1860 da Musa, Ceçen halkının mülkiyet hakları ve siyasal özerkliğini kazanması koșuluyle kabul etti. Koşullar kabul edildi ve uzun savaștan yorulmuş kitleler arasında oldukça sükunet meydana getirildi. Musa da kendi hesabına oldukça memnundu. Kendi formulü gerçekleșiyordu. Şâmil'in bütün programının en kücük bir kısmı gerçekleșememiş ise de Musa'nın programı öyle değildi. Formulünü genişletmek ve Dağıstan'ın diğer eyaletlerine, Terek ve Kubana yaymak için nufuzunu uygulamaya koymak ümidiyle avunuyordu. Nihayet Musa Kundukhov ve Ceçen halkı ümitlerinin boșa çıtığının ve 
kendilerini acı bir hayal sükûtunun beklediğinin farkına var-
makta geçikmiyeceklerdi.

Batı Kafkasya savașı sona erince, Rus hükümeti vaidini, bütün insani ve dini kanunları küstahça geri aldı ve Cerkes meclislerini (parlamento) kaldırdı (1846). Bu günden itibaren Kafkas tarihinde facialarla dolu bir sahife bașlar.

Pușkin tarafından yazılan "iki bașlı kartal" șiddet içinde Kafkasya üzerine kondu ve yenilen ulusun öldürülen cesedini demir pençeleriyle yakaladı. Kurtarıcı Car'ın (!) hükümeti yeni istila edilen ülkeyi düzene koymağa koyuldu. Bu görülmemiș derecede gürültülü bir devir oldu. Hristiyanlığın zorla yayılması, bedeni cezaların konulması, yerli gelenek ve ulusal mukaddesatla kiși hak ve dokunulmazlığına saygısızlık medeni istilâların ilk ișleri oldu. Kafkas halkı üzerine dehșet ve ümitsizlik salan bu istilaları hiç bir șey tuttukları yoldan ceviremedi.

Elisee Reclus'e göre bu kargașalığın bașlıca faili, 1864 teki son savașın hemen ardından, Dağlılara bir ay zarfında topraklarını bırakıp gitmedikleri takdirde kendilerine savaş tutsakları nizamnamesinin uygulanacağını ilan eden ve imparatorun öz kardeși olan Grandük Mișel Nikolyeviç'ten bașka kimse değildi.

Musa bu insanlık dıșı hükmün nasil uygulandığını ve kendi kabilesinden olan insanlara ait toprakların tamamen subaylara ve Kazaklara verilmek üzere nasıl gasbedildiğini gözleriyle gördü.

Șunu da söyliyeyim ki, bir kolonizasyon tarzı neticesi olarak bir Dağlı ailesi bașına ortalama yarım desyatinlik arazi düșerken bir Kazak ailesine 29 desyatinlik arazi düşüyordu.

Bu açık eșitsizlik intilale kadar devam etti ve bugüne kadar düzene girmedi.

Musa bütün kudretiyle bu haksızlığa karșı savaștı, arada da raporlar gönderdi; yüksek makamları, Nikolaev, Arkhon, Sunla, Karabulak ve diğer Kazak köylerinin kaldırılması gereği hakkında iknaa çalıștı. Nihayet hic olmazsa Kazaklar ve yerliler arasında eşit bir arazi payı yapılmasına istedi .

$\mathrm{Ne}$ yaptı ise fayda vermedi. Ne ricalar, ne de belgeler göz 
önüne, alındı. Musa o zamana kadarki hizmetlerinden de pișmanlık duydu ve istifaya karar verdi.

Bu general, uniforma, gösteriș, șan ve șeref gibi şeyleri ciğneyerek Rus düșmanı bir ihtilalci oldu ve uzun uzun düșündükten sonra, Musa, bugün siyasi bakımdan hak verilmeyecek bir karar verdi, ailesi ev kabilesi ile beraber gidip Türkiye'ye yerleșmek.

Diğer taraftan Musa bu maneviyatı kırılmıș göcmen kitlesinin içinde bulunmakla, Kafkasya'nın boșaltılması hakkında Haziran 1864 tarihli fermanı yayımlayan Petersburg efendilerinin ekmeğine yağ sürmüș oluyordu. İyi bir idareci ve kahraman bir savașç olan Musa burada aynı kudrette bir siyasi olmadığını gösterdi.

Ne karșı görüșlü dostları, ne düșmanları Türkiye'ye kaçıșını desteklediler. Șunu da ekleyelim ki, Rus hükümeti böyle karıșık bir zamanda tecrübeli bir generalini, özellikle düșman bir ülkeye katılması bahasına da olsa, elden kaçırmak istemezdi.

Türkiye'deki Hüseyin Pașa ve Berzeg Ali Pașa gibi hemșehrileriyle hareketinden evvel yaptığı haberleșmelerde onlar da göc düșüncesini kabul etmemișler, hiç olmazsa acele etmemesini istemișlerdi. Fakat Musa kararında ısrar etti. Osmanlı hükümetinden Anadolu'da mıntıka mıntıka göcmenleri yerleștirmek fermanını alır almaz kitlece Türkiye'ye hicret lehinde propagandalara giriști. Türkiye'ye gelince, bu meseledeki tuttuğu yol doğaldı. Cünkü feci vaziyette kalan dindașlarından bir melcei esirgiyemezdi.

Kuşkusuz önce Kırım'da, sonra Kafkasya'da meydana geIen boșluğa yerleștirilen ve Anadolu sınırlarına kadar dayanan Rus kolonizasyonu hic bir aklı bașında Türkün hoșuna gitmezdi. Böylece her iki taraf için de zararlı olan bu göçü tahrik eden Musa Kundukhov ne Türkiye'ye, ne Rusya'ya çalıșmış sayılır; bir cıkarı olmadığı için de itham edilemez.

Mali durumu cok parlaktı ve Rusya'da kalsaydı daha iyi olurdu. Çünkü o sırada Grandük Mișel, Loris Melikof ve șahsi

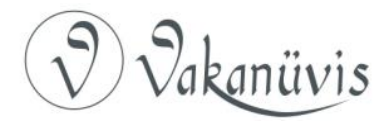



dostu general Kartzef kendisine istediğinde Kafkasya'da geniș
araziler önermișlerdi.

Bununla beraber, göc dalgası coktan bașlamıștı: 1859 da (birinci göc). Daha Musa barıș projeleri ile uğrașırken durum trajik bir genișlik kazanmıștı. Burada özellikle söylemek gerekir ki, bu göç dalgası Ruslar tarafından yalnız süngü kuvvetiyle zorlanmakla kalmayıp, hükümet tarafından halkın dini akidelerine yapılan taaruzla kitleyi ruhi bir çözülmeye sürüklemekle de destekleniyordu. Bu Musa Kundukhov üzerinde de etkisini gösterdi.

1 Ocak 1866 tarihli "Revue des deux Mondes" da Ed. Dulaurier bu hususta șöyle yazıyor:

"Cerkesler için Türkler dost ve mukaddes bir milletti. Sultan hakiki müminlerin padișahı ve kendilerine yardım edebilecek en kudretli hükümdar olarak telakki ediliyordu. Sultanların ülkesi, içinde refah ve saadetle yașanacak bir sığınak yeri olarak görülüyordu. Orada elde edecekleri topraklar, Rusların kendilerinden süngü ve ateș zoruyla gasbettikleri yerleri kat bekat telafi edecekti".

Kuban'da kalanların kendilerine verdikleri öğütlere: «Burada kalmanın iyi olacağını yadsımıyoruz, fakat biz müslüman kardeșlerimizin arasında yașamak ve nefesimizi mukaddes bir toprakta vermek istiyoruz»diye cevap veriyorlardı.

Musa Kundukhov Ceçenlere ve Kușhalara da Türkiye'ye geçmeyi așağı yukarı aynı sözleri ileri sürerek tavsiye ediyordu. Șu farkla ki: sonradan Türkler tarafından örgütlendirilmiș ve desteklenmiș bir göcmen ordusu ile tekrar gelerek iğrenc Ruslardan ülkeyi kurtarmayı ümit ediyordu.

Ve Musa Kundukhov ailesi (karısı, Kubatı, büyük oğlu Aslan Bey ve kücük oğlu bir yașındaki Bekir Sami (1), akrabaları ve așağı yukarı 3000 hane kadar olan kabilesiyle) Kafkasyayı terkederek Erzurum yolu ile Türkiyeye gecti. Musa iyi karșilandi ve kendisine Pașa rütbesi verildi. Tokat civarında Batmantaş'ta yerlești ve orada 1877 - 1878 harbine kadar yașadi.

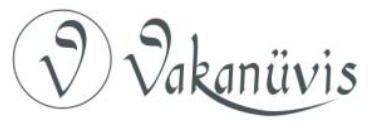


Kendisiyle beraber Türkiyeye genc bir subay ve kıymetli bir şair olan Temirbulat Mansurati de göcmüștü. Batmantaş'ta öldü ve orada defnedildi. Mansurati'nin şahsiyle Asetin edebiyatı yeri doldurulamayan bir kayıba uğradı. Genellikle Dağlıların ülkelerini terkedișlerini terennüm eden șiirlerinin kuvvet ve karakteriyle Mansurati «Lamartine»e benzetilirdi. Maalesef eserlerinin coğu yayımlanmadığı için Batmantaș yangınında mahvoldu veya ölümünden sonra kayboldu.

Az sonra Șamilin oğlu Gazi Muhammed Pașa, Fazıl Pașa gibi kișiler de Türkiye'ye göç ettiler.

Türkiye'de, bașlarında Musa Kundukhov Pașa ve Șamil'in oğlu Muhammed gibi șahsiyetler bulunan büyük bir Kafkas göcmen kitlesinin (așağı yukarı 1.500.000) bulunması, Rusları endișelendirmekten geri kalmıyordu (1877 - 1878). Bunun içindir ki, bu uğursuz harpten üç sene kadar önce Rus hükümeti, bu iki pașa ile Kuzey Kafkasya'da kalan halkı Afgan sınırına naklederek orada bir Yeni Kafkasya kurmak hususunda görüșmek üzere general Fadel'i İstanbul'a gönderdi. Bu devlet Rus himayesi altında özerk olacaktı. Nakil ve yerleșme masraflarını Rusya tekeffül ediyordu. Bu öneri Gazi Muhammed ve Musa Pașa tarafından göcmen Cerkeslerin dindașları olan Afkanlılara karșı silahlanmak istemedikleri ileri sürülerek reddedildi.

Rus hükümeti gerçekte, Ingiliz tesir sahasında ve Afgan hududunda bir Kafkas tampon hükümeti kurmayı tasarlıordu, yoksa böylelikle, Türkiye'de bulunmasını kendi emelleri için zararlı gördüğü bir Kafkas göcmen kitlesini zararsız bir hale getirmeyi mi kuruyordu? bilinmez.

Ne olursa olsun bu sonuncu varsayım Car hükümetinin siyasi prensibiydi. Musa Pașa ve Gazi Muhammed Kafkas gönüllülerinin bașında ve Osmanlı Müșiri Ahmet Muhtar Pașa kumandasında, Rus - Türk harbinde Anadolu cephesinde faal bir rol oynadılar. Bu seferde, Musa Pașa önce bir süvari birliği bașında Benli Ahmet ve Vladikars'ta, sonra da Anadolu ordusu erkanıharbiyesinde kumandanlık kabiliyetini isbat etti ve ismi askeri ansiklopediye geçti. 
Bu durum, Ruslar tarafından Musa Pașa hakkında "Hain Kundukhov Pașa» adında yakın zamana kadar söylenen bir marş
cıkarılmasına neden oldu.

Berlin anlaşmasıyle sona eren bu harbin sonucu belli, zaten zayıf olan Osmanlı devleti savașı kanlı bir şekilde kaybetti. Musa Paşa'nın Kafkasya'ya tekrar gidip özgürlüğünü iade etmek rüyası da tamamiyle söndü. Darbe bu kadarla kalmadı. Rus Türk savașının bașlamasiyle beraber Dağistan ve Cecenistan'da ayaklanan halk katliama uğradı ve Türkiye'ye ikinci ve facialarla dolu bir göc bașladı ve Musa Pașa Erzurum anahtarlarını rakibi Loris Melikofa teslim etti.

Böylece Moskoflar ummadıkları kadar semereli bir zafer elde ediyorlar, ayni zamanda hürriyet așıkı Kafkasa da ikinci bir tutsaklık zinciri vuruyorlardı.

Musa Pașanın eneriisi kırılmıștı. Ordudán çekildi ve ömrünün geri kalan kısmını Erzurum'da sükûnetle geçirdi. 1889 da orada öldü. Mezarı Narmanlı camiinde kardeși ve Șamilin eski silah arkadașı Hazbulat Beyinkinin yanındadır.

Fakat Ruslar bu ölüyü de rahat bırakmadılar. Büyük harpte (1915) Erzurum'u tekrar işgal ettiklerinde camii ve mezarı yıktılar. Bu hayacızca hareket bu kanlı dönemin son sahnesi oldu. Sonra bolșeviklik geldi (Veyl mağluplara).

\section{Gazi Ahmed Muhtar Paşa'ya "Ariza"}

Rusların takibinde olan IV. Ordûy-u Hümâyûn birlikleri Şüregel düzlüklerinde ve Arpaçay taraflarına kadar Rus çekilişini sağlamış ve şimdilik zafer kazanmış görünmekte idi. Ancak, sonbahar 1877'de, Ruslar yeni bir strateji ile karşı hücuma geçmiş ve geri çekilişi de düzenli bir ilerleyişe çevirmişlerdi. Şüregel'deki düzlüklerdeki birçok yerde mevzilenen Ordûy-u Hümâyûn, özellikle Alacadağ mevziinde zorlanmaya başlamıştı. Şiddetli savunma ve çıkış atılımları da sonuçsuz kalınca, 'felaket' ve sonra da tam bir' hezimet' durumları yaşanmaya başlanmıştı. 9-15 Ekim 1877'de Türkler, üstün ve donanımlı Ruslar karşısında, soğukların başlaması, iaşe ve ibadetenin de yok olma derecesine geldiği bir sırada zirveleri kar bürümeye başlamış Alacadağ'da, Ferik Ömer, Hacı Raşid, Mirlivâ Hüseyin ve Musa Paşa

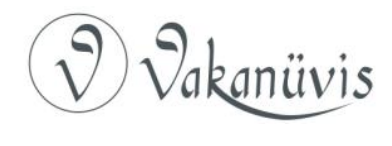


kumandasındaki birlikler pek başarılı olamadı ve genel bir çözülme gözlendi. Bunlar içinde sadece Musa Paşa başının çaresine bakmak zorunda idi. Öbür Paşalar, sözleşme gereği hayatını kurtarabilirlerdi ama Musa için böyle bir durum hayal edilemezdi. Ekim 1877 hadiseleri daha sonra üç küçük eser ile tarihe ışık tutmuştur. İlki "Alacadağ'da terk-i silah ederek, düşmana teslim olmuş olan Ferik Raşid ve Erkan-ı Harbiye Mirlivası Hasan Kazım Paşalar ile Ümera-ı Sâ'ire Anadolu Divan-ı Harbinde lede'l- muhakeme haklarında terettüb eden hüküm mazbatasıdır". Bunun basılış yeri ve tarihi İstanbul 1296 olup Alacadağ Vakıasının nasıl cereyan ettiğini ortaya koymaktadır. Alacadağ Savaşları hakkında bir başka risale de Rus General Loris Melikov'a aittir. Alacadağ ve Obruk Muhabereleri (2-3 Teşrin-i Evvel 1877 )" adını taşıyan eseri de Binbaşı Nazmi Bey, Rusça'dan Türkçeye çevirmiştir. Ankara 1339 (1923). O da daha sonra, ordu komutanına kendi açısından değerlendirilen Ariza/ Risaleyi tertib ve arz etmiştir. Bu, " Alacadağ vakası hakkında Musa Paşa'nın Gazi Muhtar Ahmet Paşa'ya takdim ettiği arizadır. İstanbul'da basımı yapılan risaleye dair basım tarihi mevcut değildir.
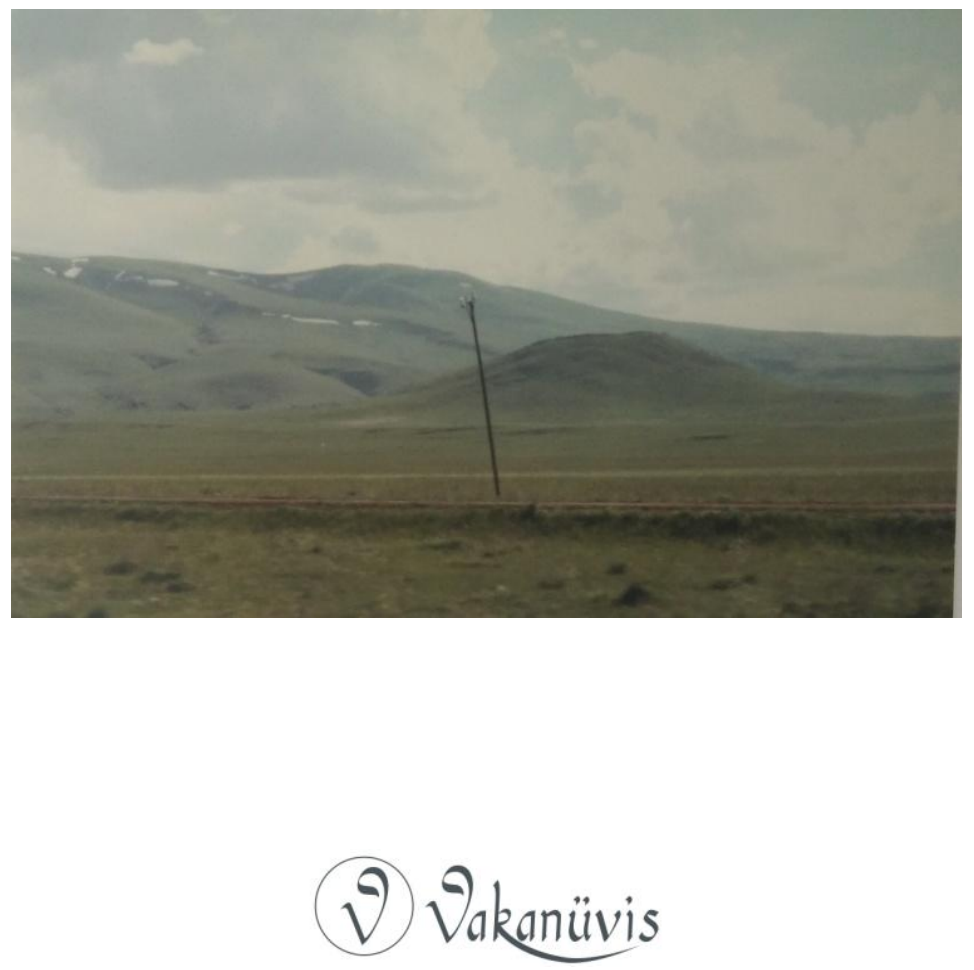


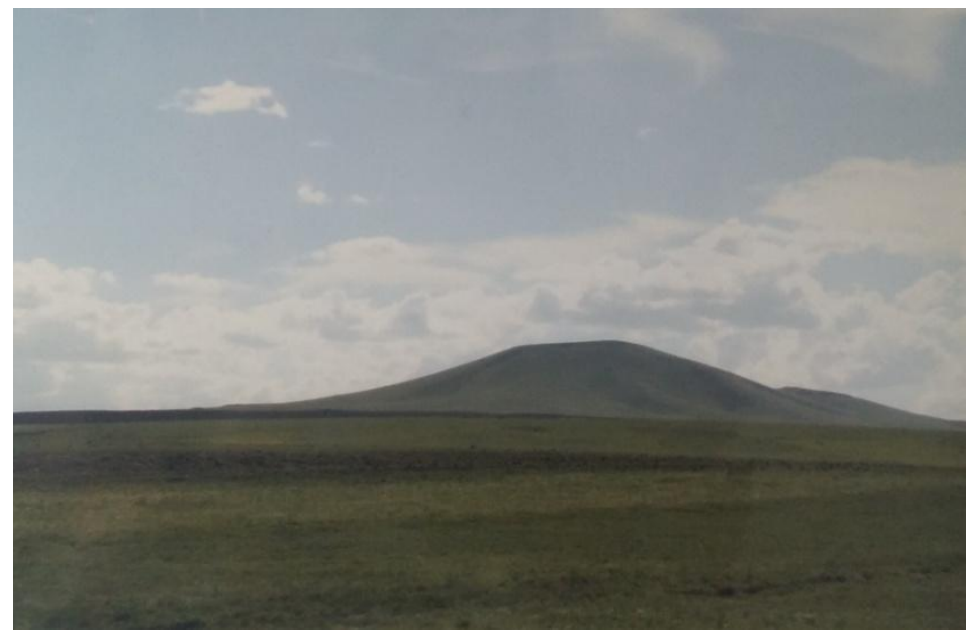

\section{Alacadağ, Kars}

Musa Paşa'nın da Alacadağ'dan sağ salim kurtuluşu oldukça önemlidir. ve sebepleri üzerinde de hem gazi Ahmet Muhtar Paşa ve hem de Mehmed Arif Bey tarafından Şöyle ifade edilmiştir.

"Umumi kararğah olan Alacadağ'da, yirmi altı tabur kaldı. Bunun dördü dağın tepesine çıkarıldı. Güney yüzüne bakan, yani çevirme harekâtı edecek olan yere Musa Paşa kumandası ile konulmuştur... 13 Ekim 1877'de, Alacadağ'ın tepesinde bulunan Musa Paşa'dan haber alındı. Ruslar, bulunduğu Alacadağ'ın ilerisinde idi, Söğütlü köyünden şimdi çıktı ise de, kuvveti hakkında bilgi alınamamıştır..."

Gazi Muhtar Paşa'nın yanında bulunan katib Mehmet Arif Bey 'de bazı detayları farkı bir şekilde vermekte. "Çünkü Musa Paşa eski Rus generallerinden idi. Alacağ'dan on yıl kadar önce Osmanlı'ya hicret ve iltica etmişti. Eğer bu defa yakası ele geçerse mutlaka kurşuna dizilecektir. Kurşuna dizilmese bile düşmanın içinde bulunan eski arkadaşlarının yanına esir olarak gitmek gibi bir âr'a tahammül edemeyeceğinden teslim olmamaya iyice karar vermiştir. Diğer komutanlar teslim kararı aldılar ve uyguladılar. Gece olmuştu, Musa Paşa taburlarının yanına gitti, kendisinin teslim olmayıp savaşacağını ilan etti. Bir Binbaşı ile Erkan- Harbiye Kolağalarından Danyal Efendi de bu görüşe uydu ve yanında kaldılar. Musa Paşa, geceleyin

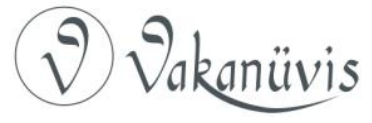


Alacadağ'dan çıkış ve inişi denedi. Rusların ileri karakoluna rastladı. Fakat Rusça yüksek sesle, hale ve duruma münasip bazı sözler söyledi. Karakol neferleri de kendisini Rus zabiti zannederek. Geçmesine mani olmazlar..."

Ahmet Muhtar Paşa hezimetin iyice yaklaştığını görünce Kars şehrine ve sonra da batıya han Suyu vadisine, oradan da Horasan'a Köprü Köy'e çekilme kararını verdi. Musa Paşa'da elinden geldiğince verilen emre uydu ve büyük kayıpları önlemiş oldu. Ama çekilişte epey karışıklık da zuhur etmiştir.

Musa Paşa askerlik mesleğinin gereği, bu nedenlerle, kendine kuvvetlerinin durumu hakkında sonraları "Ariza" kaleme almıştır.

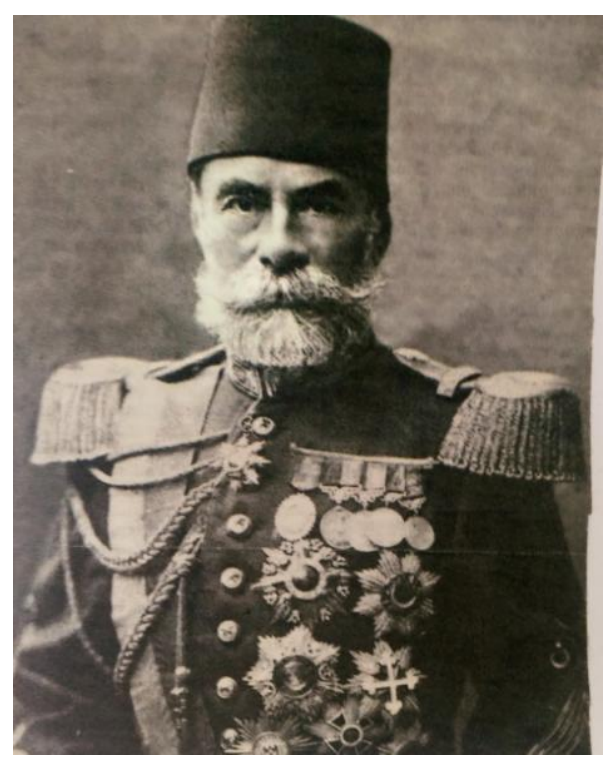

Gazi Ahmed Muhtar Paşa

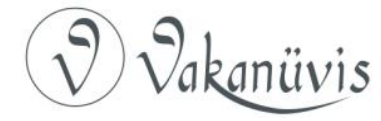




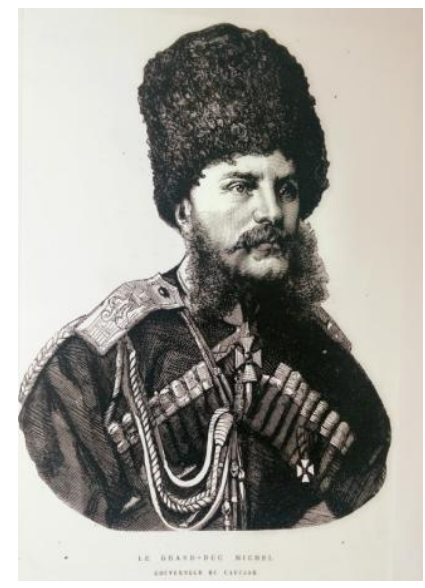

Kafkasya Valisi Mihail

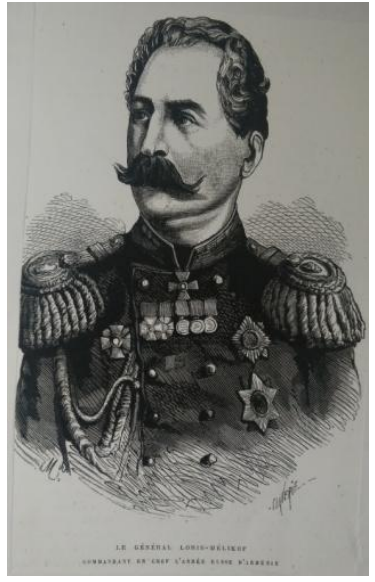

Loris Melikov

\section{Kaynakça}

Ahmed Mithat Efendi, Zübtetü'l-Hakayık, hzl: Ö. F. Can, Ankara 2015.

Baddeley, John F., Rusların Kafkasyayı İstiası ve Şeyh Şamil, çvr: S. Özden, ìstanbul 1989.

Basiret Gazetesi, no: 224317 Teşrin- evvel 1293/1877, 1.

Çam, N., Erzurum Tabyaları, Ankara 1993.

Edward, William, David Allen- P. Muratov, 1828-1921 Türk Kafkas Sınırındaki Harplerin Tarihi, Ankara 1966 (Caucasian Battefields: A History of the Wars on the Turco- Caucasian Borders 1828-1921, Cambridge 1953).

Gavin, Catrine, The House of War, Newyork 1970.

Gazi Ahmet Muhtar Paşa, Anılar: Sergüzeşt-i Hayatımın Cild-i Sanisi, hzl: Y. Demirel, ìstanbul 1996.

Greene, W., The Russian Army and its Campaigns in Turkey, Newyork 1879.

Kaptan Mehmed Paşa Dosyası, Erzurum 2011.

Kutlu, T. C., "Çerkes Musa Kundukhov Paşa (1818-1889)", Tarih ve Toplum, sayı: 36 Aralık 1980, s. 47-48.

Küçükuğurlu, M., Erzurum Tabyaları ve Kışlaları, İstanbul 2013.

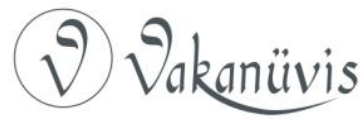


Les Memories du General Mouusa Pacha Kundoukhov (1837-1865), Paris 1939.

Mahmud Celaleddin Paşa, Mir'at-ı Hakikat, hzl: İ. Miroğlu, İstanbul 1983.

Mehmed Arif Bey, Başımıza Gelenler, hzl: E. Düzdağ, İstanbul 2009.

Muhammed Tahirü'l- Karakhi, Imam Şamil'in Gazavatı, çvr: Tahirü'lMevlevi, hzl: T.C. Kutlu, İstanbul 1967.

Osmanlı Belgelerinde Kafkas Göçleri, (Proje Yöneticisi: Prof. Dr. Uğur Ünal), İstanbul 2012.

Sultan II. Abdülhamid ile Erzurum Vilayeti Arasındaki Yazışmalar (1894/1906), Hzl: M. Demirel, İstanbul 2007.

Sükan, S., Osmanlı Devri, 1877-1878 Osmanlı Rus Harbi, Kafkas Cephesi Harekatı, Ankara 1985.

Şükürov, Kerim K., Türkmençay-1828, Bakü 2006, s. 73-80.

TBMM Albümü, Ankara 1994, s. 2. Buradaki ölüm tarihi 16 Ocak 1933'tür.

Tozlu, Selahattin, Zivin Savaşından Berlin Antlaşmasına Kadar Erzurum (1877/1878), Atatürk Üniversitesi Sosyal Bilimler Enstitüsü Tarih Eğitimi ABD, Basılmamış Yüksek Lisans Tezi, Erzurum 1991.

Uçarol, R., Gazi Ahmed Muhtar Paşa: Bir Osmanlı Paşası ve Dönemi, İstanbul 1976.

Ünal, M., Kurtuluş Savaşında Çerkeslerin Rolü, İstanbul 1996.

von Schuluga, Rudolf, 1295/1877 Osmanlı- Rus Seferinde Haliyas-ZivinKars Muharebeleri, çvr: Yakub Şevki, İstanbul 1326/1910. 